\title{
Role of Bifidobacteria on Infant Health
}

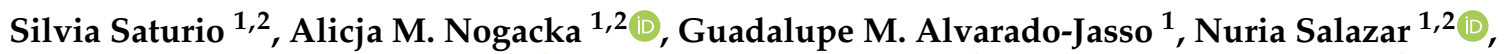 \\ Clara G. de los Reyes-Gavilán ${ }^{1,2}\left(\mathbb{D}\right.$, Miguel Gueimonde ${ }^{1,2, * \mathbb{D}}$ and Silvia Arboleya ${ }^{1,2, *(\mathbb{D})}$ \\ 1 Department of Microbiology and Biochemistry of Dairy Products, Instituto de Productos Lácteos de \\ Asturias (IPLA-CSIC), 33300 Villaviciosa, Spain; silvia.saturio@ipla.csic.es (S.S.); \\ alicja.nogacka@ipla.csic.es (A.M.N.); gpemonserratjasso@gmail.com (G.M.A.-J.); nuriasg@ipla.csic.es (N.S.); \\ greyes_gavilan@ipla.csic.es (C.G.d.l.R.-G.) \\ 2 Diet, Human Microbiota and Health Group, Institute of Health Research of the Principality of Asturias (ISPA), \\ 33011 Oviedo, Spain \\ * Correspondence: mgueimonde@ipla.csic.es (M.G.); silvia.arboleya@ipla.csic.es (S.A.); \\ Tel.: +34-985-892131 (M.G. \& S.A.)
}

check for updates

Citation: Saturio, S.; Nogacka, A.M.; Alvarado-Jasso, G.M.; Salazar, N.; de los Reyes-Gavilán, C.G.; Gueimonde, M.; Arboleya, S. Role of Bifidobacteria on Infant Health. Microorganisms 2021 9, 2415. https://doi.org/10.3390/ microorganisms 9122415

Academic Editor: Claudio de Simone

Received: 18 October 2021

Accepted: 21 November 2021

Published: 23 November 2021

Publisher's Note: MDPI stays neutral with regard to jurisdictional claims in published maps and institutional affiliations.

Copyright: (c) 2021 by the authors. Licensee MDPI, Basel, Switzerland. This article is an open access article distributed under the terms and conditions of the Creative Commons Attribution (CC BY) license (https:/ / creativecommons.org/licenses/by/ $4.0 /)$.

\begin{abstract}
Bifidobacteria are among the predominant microorganisms during infancy, being a dominant microbial group in the healthy breastfed infant and playing a crucial role in newborns and infant development. Not only the levels of the Bifidobacterium genus but also the profile and quantity of the different bifidobacterial species have been demonstrated to be of relevance to infant health. Although no definitive proof is available on the causal association, reduced levels of bifidobacteria are perhaps the most frequently observed alteration of the intestinal microbiota in infant diseases. Moreover, Bifidobacterium strains have been extensively studied by their probiotic attributes. This review compiles the available information about bifidobacterial composition and function since the beginning of life, describing different perinatal factors affecting them, and their implications on different health alterations in infancy. In addition, this review gathers exhaustive information about pre-clinical and clinical studies with Bifidobacterium strains as probiotics in neonates.
\end{abstract}

Keywords: bifidobacteria; gut microbiota; health; development; early life; infant; probiotics; disease

\section{The Genus Bifidobacterium: A Landmark of the Healthy Breastfed Infant}

Correct gut microbiota acquisition during the early stages of life constitutes one of the critical processes that will determine the later health of the individual [1,2]. Among the microorganisms present in this early life microbiota, the genus Bifidobacterium plays a crucial role, having an important function in newborns and infant development [1]. Bifidobacteria were first described at the beginning of the 20th century by Tissier (1900) (originally named Bacillus bifidus) after isolating them from breastfed infant feces [3]. Later, they were included in the family Lactobacillaceae (Lactobacillus bifidum) until 1924, when L. bifidum was reclassified as the new genus Bifidobacterium by Orla-Jensen [4]. The genus Bifidobacterium belongs to the phylum Actinobacteria and currently comprises 94 recognized (sub)species; most of them are normal inhabitants of the gastro-intestinal tract of humans and animals [5]. They are strictly anaerobic, although some species tolerate moderate oxygen levels [6]. The genus comprises high $\mathrm{G}+\mathrm{C}$ Gram-positive, non-spore-forming, non-motile, and non-filamentous polymorphic rod-shaped bacteria, which can show a large variety of branchings, with bifurcated or spatulated cellular ends being the most common shapes [7]. During recent years, this genus has been extensively studied due to both its important role within the human intestinal microbiota and the extensive use of certain Bifidobacterium strains as probiotic products [5,8-10].

In the human gut, bifidobacteria are among the predominant microorganisms during infancy, being the dominant microbial group in healthy breastfed infants [1,11]. At this stage, the microbiota is composed mainly of Actinobacteria, the genus Bifidobacterium being the main representative, with relatively high levels of Proteobacteria as well [1]. Later, with 
the introduction of complementary foods and breastfeeding cessation, they are replaced as a dominant microbial group by other microorganisms [12]. The characteristic microbiota of adults is dominated by the phyla Firmicutes and Bacteroidetes and during this period of life, bifidobacteria remain relatively stable trending to a decrease at senescence [13-15].

It is generally accepted by the scientific community that the gut microbiota composition, and consequently the dominance of specific species of the genus Bifidobacterium, of healthy full-term, vaginally delivered, and exclusively breastfed infants is the standard for healthy infant microbiota development [16]. Traditionally, the higher level of bifidobacteria observed in breastfed infants has been attributed to the presence of bifidogenic oligosaccharides in breast milk $[17,18]$. However, breast milk also contains commensal bacteria (staphylococci, streptococci, lactic acid bacteria, and bifidobacteria) [19-22], which may also play a role in the dominance of this microorganism observed in breastfed infants. Moreover, the fact that breast milk promotes correct neonatal microbial and immune system development, prevents several non-communicable diseases, and improves cognitive outcomes [23-26] has prompted the industry towards the supplementation of infant formulas with these microorganisms.

The early life dominance of bifidobacteria is of relevance since these microorganisms are considered beneficial and reduced levels of them have been associated with poor health or disease conditions [10,27], including immune and metabolic disorders [28-30]. Not just the alteration on the genus Bifidobacterium levels, but also on the profile and quantity of the different bifidobacterial species present has been demonstrated to be of relevance to health $[10,31,32]$. Moreover, the species Bifidobacterium adolescentis, Bifidobacterium animalis, Bifidobacterium bifidum, Bifidobacterium breve, and Bifidobacterium longum have the Qualified Presumption of Safety (QPS) status granted by the European Food Safety Authority (EFSA) [33], which has promoted the use of some bifidobacterial species as probiotics in different food products and supplements by the industry.

Some bifidobacterial strains have showed resistance phenotypes to different antibiotics, such as aminoglycosides, metronidazole, mupirocin, streptomycin, polymyxin B, erythromycin, or tetracycline. Some of these resistances are intrinsic due to a lack of cytochrome-mediated drug transport or the presence of an atypical isoleucyl-tRNA synthetase, which represents a low risk of transferability. In other cases, the resistance is because of punctual mutations in specific genes and the risk of transferability remains low. However, the resistance to erythromycin or tetracycline, for example, has been found in transposases or in genes flanked by transposases. Notwithstanding, most of the Bifidobacterium strains are susceptible to macrolides, vancomycin, beta-lactams, rifampicin, or chloramphenicol [34].

The species most commonly present in humans include B. adolescentis, Bifidobacterium angulatum, B. bifidum, B. breve, Bifidobacterium dentium, Bifidobacterium catenulatum, Bifidobacterium pseudocatenulatum, B. longum, and Bifidobacterium pseudolongum [35], whereas $B$. animalis subsp. lactis is the species more often included in functional foods and food supplements [36]. Interestingly, some species, such as B. adolescentis, B. pseudocatenulatum, or B. catenulatum, are often more abundant in adults [37-39]. In babies, $B$. longum subsp. longum and B. longum subsp. infantis, together with B. breve and B. bifidum, are the most commonly found, although the Bifidobacterium species composition will be affected by different perinatal factors [32,40]. B. longum subsp. longum is the species that predominantly inhabits both the infant and adult intestines [41]. It is also important to underline that bifidobacteria show a strong ecological specialization that restricts these microbes to the animal gastrointestinal system; moreover, species specialization seems to exist, with the species distribution depending on environmental factors, host age, and localization in the intestine [32,35,37,42].

The moment at which the microbiota, in general, and bifidobacteria in particular, colonize the human gut is still controversial. Some authors have suggested that colonization may start in utero [43,44], whereas others suggest that colonization starts at delivery [45,46]. In any case, after a very early initial colonization likely led by facultative anaerobic and 
aerotolerant microorganisms that last for just few hours, Bifidobacterium becomes a dominant genus in the newborn microbiota [12,32]. During recent years, several studies have reported the vertical transmission of bifidobacterial strains from mother to infant [47-49], the main bifidobacterial colonization occurring from birth and being influenced by several intrinsic and extrinsic factors $[10,50]$.

It is of relevance to underline that an aberrant bifidobacterial number or composition is perhaps the most frequently observed intestinal microbiota alteration in infant diseases. However, no definitive proof is still available on the causal association between reduced bifidobacterial levels, or altered species composition, and disease. This suggests an important role of bifidobacteria in the intestinal homeostasis, perhaps with a causal role in some diseases or as a marker of disrupted homeostasis in others.

\section{The Genus Bifidobacterium and Neonatal Health}

Mounting evidence states that there is a critical window for later health in early life when the establishment and composition of the gut microbiota is pivotal for immunological development and establishment of physiological homeostasis. This established concept, called developmental origin of health and disease (DOHaD), spans a period from conception to 2 years of life, the so-called 'first 1000 days', in which any particular set of environmental factors produce fingerprints on the genomes (encompassing microbiome and host genome), programming health and the future risk of illness of an individual for life [51]. However, it is known that particularly during the first three months of life is when aberrancies on the gut microbiota establishment are most significant in impacting the immune system development, and consequently future health [24]. Several studies carried out both in animal models and in human clinical trials have demonstrated the importance of the Bifidobacterium genus in the very earliest stages of life and reduced levels of them have been associated with disease, as it was stated above [10,24]. Thus, exposure to suitable factors during the initial stages of life is crucial and it is of great interest to unveiling how gut microbiota, and in particular the bifidobacterial community, is shaped by them in this period.

\subsection{Starting Foundation of Health: Bifidobacteria in the Dyad Mother-Infant}

Mothers provide the first microbial inoculum for the child and this fact influences the later health. As babies pass through the birth canal, they come in close contact with several members of their mother's vaginal, skin, and fecal microbiota, with this being considered by the scientific literature as the colonizing inoculum, which will give rise to a healthy infantile intestinal microbiota, if the conditions are optimal [1]. Over the last few years, numerous studies have supported the hypothesis of microbiota's vertical transmission from mother to children [47-49,52-54]. Makino et al. explored the relationship between mother and infant intestinal bifidobacteria by using multilocus sequence typing and observed that five bifidobacterial strains were monophyletic between individual mother and infant pairs and were found over time in infant fecal samples [48,55]. Moreover, they described that the former strains were only present on vaginally delivered infants, suggesting that delivery mode may influence the mother-to-infant transmission of strains. Using a more exhaustive technique by sequencing the 16S-23S rRNA gene internal transcribed spacer, other authors observed that mothers and infants shared identical bifidobacterial strains and bifidobacterial communities $[49,56]$. In particular, two strains belonging to B. breve and B. longum subsp. longum were observed to be transferred from mother to infant and persisted over six months of life. Using a combination of strain-specific pangenome-based metagenomics and genetics-based methods, the same sequence identity on different Bifidobacterium strains in the infant-mother dyad was also observed, such as with the species B. bifidum and B. longum $[57,58]$. The role of breastfeeding in this transmission has also been underlined. Different studies have shown that the same bifidobacterial species present in breast milk were found in the feces of breastfed infants over time [59,60]. Cortés-Macías et al. [61] recently studied pre-gestational body mass index, weight gain during pregnancy, and 
breastfeeding practices as factors affecting breast milk's profile variability. Their results showed higher levels of bifidobacteria in average-weight women who exclusively breastfed their infants. In another study, the maternal dietary profile was assessed, observing that higher fiber and carbohydrates intake was related to a higher relative abundance of the genus Bifidobacterium in breastmilk [62]. These studies demonstrate that different factors can alter the bifidobacterial transmission through the breastmilk to infants, this being considered as the optimum feeding mode for neonates.

Breast milk is not only a source of bifidobacteria, but it also favors its growth by providing bioactive compounds like human milk oligosaccharides (HMOs) [63]. Bifidobacterium members are perfectly adapted to the colonic area due to a process of coevolution and they are able to use the diet-derived glycans and host-provided carbohydrates (mucin and HMOs) as a carbon source, which play a pivotal "prebiotic" role promoting the growth of beneficial bacteria and the establishment of correct gut microbiota in early life [64]. The species B. longum subsp. longum, B. longum subsp. infantis, B. bifidum, or B. breve, which are generally predominant in the infant gut, can break down HMOs into mono- and disaccharides, providing these microorganisms with a competitive advantage and contributing to a cross-feeding interaction with other gut microbiota members [65]. Moreover, bifidobacteria produce short-chain fatty acids (SCFAs) by fermentation of HMOs, mainly acetate and formate, but also other acids, such as lactate and 1,2-propanediol, with beneficial effects on the host [66-68]. In this sense, in a recent study, Henrick et al. demonstrated that a depletion on the HMOs-utilizing bifidobacterial genes from the fecal microbiome was linked to systemic and intestinal inflammation and immune dysregulation markers at the beginning of life [24].

\subsection{Bifidobacterial Features Contributing to Beneficial Action in the Early Gut}

Bifidobacterium members carry out their beneficial contribution to the infant by interacting with the gut through different cellular structures, such as surface-associated exopolysaccharides, pilis, or serpins, that allow the adhesion of bifidobacteria to enterocytes and trigger proinflammatory responses that take part in the development of the immature immune system $[1,69,70]$. In vitro assays demonstrated how Bifidobacterium strains protect the host by preventing the disruption of the intestinal epithelial barrier and increasing the expression of integrant proteins [71] and by competition for nutritional resources. He et al. [72] observed differences in the adhesion capacity between different species of bifidobacteria, in the context of studying the gut microbiota of infants with allergies. The bifidobacterial community of these infants was dominated by B. adolescentis, unlike in healthy children, in which B. bifidum was predominant. The results of this study showed that adhesion to intestinal mucus was significantly higher in the group of healthy individuals, favoring the colonization of the gut by bifidobacteria members that consume resources and nutrients, thus limiting pathogen establishment [69]. In addition, some species produce bacteriocins with inhibitory activity against pathogens [73] and thanks to the action of acetic acid produced, it was observed that bifidobacteria are able to protect against infection caused by the pathogen Escherichia coli O157: H7, by preventing the toxin from spreading through the bloodstream [74]. Other beneficial effects on infant health include folate production in the intestines or increased immune responses to vaccinations $[75,76]$.

\subsection{Perinatal Factors Affecting Bifidobacteria and Health}

Several early life situations may impact early microbiota, and consequently bifidobacteria establishment, influencing later health (Figure 1). 


\section{FACTORS SHAPING A HEALTHY INITIAL BIFIDOBACTERIA ESTABLISHMENT}

\section{Prenatal factors}

Healthy habits during

pregnancy

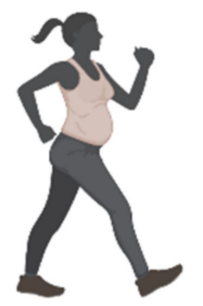

\section{Breastfeeding}

- HMOs

- Bifidobacteria

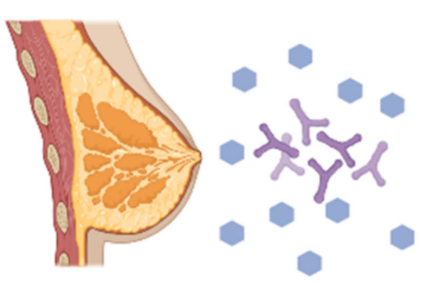

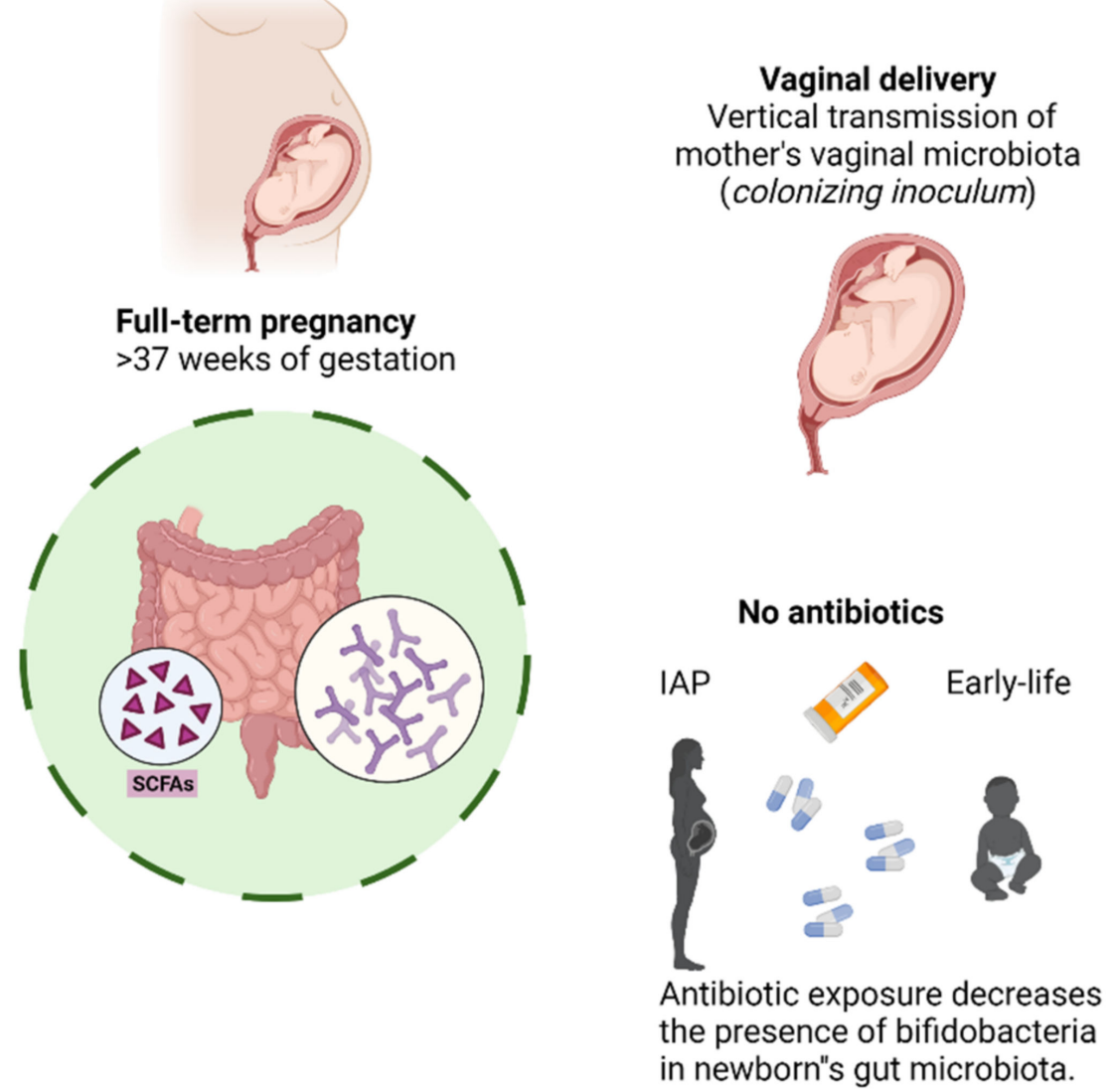

Figure 1. Factors shaping healthy initial bifidobacteria establishment.

Premature babies (born before 37 weeks of gestational age and/or with very low birth weight-VLBW-<1500 g) are more likely to have chronic health issues, such as infections (necrotizing enterocolitis-NEC-, sepsis) or asthma, impairment of growth, neurodevelopment or feeding habits, and even an augmented risk of sudden infant death syndrome. Prematurity is one of the factors affecting correct gut microbiota colonization, since consistent observations demonstrated an increased presence of opportunistic and potentially pathogenic microorganisms and decreased levels or delayed establishment of beneficial bacteria, notably of those microorganisms belonging to the Bifidobacterium genus [77-81]. It was observed that both in extremely premature ( $<32$ week of gestation) and premature babies ( $<37$ weeks of gestation), Bifidobacterium was one of the genera most affected, with reduced levels and abundances during the first three months of life $[77,78]$. These sorts of differences have been found even at two years of life [82]. A recent study evidenced that prematurity affects bifidobacteria not only at the genus level but also at the (sub)species level; thus, premature babies showed a higher abundance of some specific species, such as B. breve, B. pseudolongum, or B. animalis subsp. lactis, along the first trimester of life than full-term infants [32].

The relationship between a low rate of colonization by species of Bifidobacterium and the incidence of pathologies, such as NEC or late-onset sepsis (LOS), during the first weeks of life has been reported in different studies [83-86]. NEC is characterized by an inflamed and necrotic intestine in later stages of the disease and is one of the most lethal diseases in preterm babies, its incidence being inversely related to gestational age and birth weight. Although the etiology of NEC is probably multifactorial and unknown, it appears that there is an inflammation in which the microbiome is involved, and it is known that breast milk protects against the development of NEC in premature babies [87]. NEC and LOS, 
defined as sepsis occurring $\geq 72 \mathrm{~h}$ postnatally, contribute substantially to neonatal morbidity and mortality at neonatal intensive care units (NICUs) and affects mainly premature infants, with serious sequelae [88]. In the study carried out by Stewart et al. [86], a negative correlation was established between the presence of bifidobacteria in the intestinal microbiota of premature children with LOS, whereas the control group (no LOS or NEC) was positively related to the presence of bifidobacteria. Considering that microorganisms causing LOS may be translocated from the intestine [89], the hypothesis defending the protective role of the genus Bifidobacterium against infections, such as those mentioned above in premature infants, is reinforced. Moreover, observational studies have linked the loss of Bifidobacterium in infants and enteric inflammation early in life [24]. Additionally, some studies associate the prevalence of NEC in premature infants carrying a mutation in the FUT2 gene (non-secretor genotype), which encodes a glycosyltransferase, with a lower abundance of bifidobacteria $[90,91]$.

On the other hand, premature babies suffer a postnatal growth failure that occurs during a critical developmental period of life and the main medical goal is reaching a weight gain and body composition in these infants similar to the fetal intrauterine growth [92]. A positive association was reported between bifidobacterial levels and weight gain in premature babies [93,94]. In a humanized mice model created by fecal transplantation from undernourished infants, B. longum was observed to be one of the most discriminatory species correlated with weight gain [95]. This species also showed a negative association with inflammation and anorexia/cachexia mediators in the same previous undernourished infant population [96] and was one of the main conserved structural members in the infant gut microbiota, a core that was defined and used to distinguish different degrees of undernutrition [97].

Delivery mode is known to be a pivotal driver of the gut microbiota composition and can influence the vertical transmission of microbiota at birth from mothers to infants $[1,98,99]$. While vaginally delivered infants acquire their microbiota from mothers with a less diverse and relatively stable composition overtime, C-section-born babies are susceptible to colonization by more microbes from the environment $[1,98]$. Despite the variability of the results on gut microbiota composition depending on the way of delivery, several studies have reported a delay in the colonization by bifidobacteria in children born by cesarean section [98,100-102], even at one year of life [103]. Moreover, a recent study also observed differences at the Bifidobacterium (sub)species level between full-term babies born by vaginal or C-section mode [32].

Antibiotic administration during gestation or at early life is another factor known to be able to modify the infant's gut microbiota. Neonates from mothers that have received intrapartum antibiotic prophylaxis (IAP) administration are characterized by higher levels of Proteobacteria and Firmicutes and lower levels of Actinobacteria and bifidobacteria $[104,105]$. It was also observed that IAP also affected bifidobacteria at the species level [106]. Antibiotic administration in full-term infants during the first hours of life led to a relative decrease in Bifidobacterium and an increase in fecal Proteobacteria [107]. A recent study that evaluated the long-term impact of antibiotic treatment in the neonatal period and early childhood on child growth also reported that neonatal antibiotic exposure is associated with a significantly decreased abundance and diversity of fecal bifidobacteria until two years of age [108]. Of utmost importance is to take into account that early life antibiotic exposure modifies the "natural" progression of the infant gut and the loss of bifidobacteria may lead several negative consequences for infant health including childhood overweight or obesity [109]. 


\section{The Genus Bifidobacterium and Child Development}

Recent evidence suggests that a failure to enhance microbial establishment during early life can result in an increased risk of childhood inflammatory diseases and contributes to an increased obesity risk and metabolic diseases in later life. During the last decade, we have started to understand that the gut microbiota and brain are connected and bidirectionally communicated, and in this two-way path, the gut microbiota can interfere with the normal function of the brain. The importance of understanding the impact of one of the most important members of the early gut microbiota, the Bifidobacterium genus, on future child development is also becoming evident.

\subsection{Bifidobacterium Genus as a Biomarker of Metabolic Diseases in Infanthood}

Obesity, particularly in children and adolescents, has become a significant public health problem that has reached epidemic levels worldwide. Recent models have predicted that $57 \%$ of today's children will be obese by the age of 35 [110]. Maternal obesity impacts on the offspring's gut microbiota and the risk for obesity and non-alcoholic fatty liver disease (NAFLD). A recent in vivo study employing germ-free (GF) mice colonized with stool microbes from 2-week-old infants born from obese or normal-weight mothers demonstrated the causative role of maternal obesity-associated infant dysbiosis in childhood obesity and NAFLD [111]. High maternal pre-gestational body mass index (BMI) is associated with an altered infant microbiome from the first days of life until 2 years of age, bifidobacteria being one of the genera most affected, and can also shape the composition and diversity of the breast milk microbiota $[61,112,113]$. Recent evidence has shown that pre-gestational normal-weight women with exclusive breastfeeding habits harbored a significantly higher abundance of the Bifidobacterium genus in the breast milk that could also have an impact on infant development and health [61]. The mother's BMI was negatively associated with Bifidobacterium levels in milk samples and positively associated with colostrum Lactobacillus and Staphylococcus levels. Therefore, breastfeeding and bifidobacteria in milk provide advantages for both mothers and infants particularly, by decreasing the risk of obesity and other metabolic-related problems [25,60].

Caesarean delivery and IAP are well-known risk factors for the gut dysbiosis of early infancy, including a reduced abundance of Bifidobacterium and Bacteroides [100,114,115], which is associated with greater risk for overweight and obesity [1,116]. However, only few studies have assessed the impact of infant gut microbiota and their metabolites on the disease development. A recent study performed with full-term infants reported that formic acid, a microbial metabolite that can be produced by the Bifidobacterium genus, is linked with infant growth. When this metabolite was present at high amounts in 3-month-old infants, it was associated with a higher abundance of Bifidobacterium at the age of one year, and subsequently with lower BMI [117]. In addition, obese children have an increased risk of developing obesity-related diseases, such as metabolic syndrome and diabetes, as well as an increased risk of mortality and adverse health outcomes later in life. Decreased numbers of fecal bifidobacteria have been detected in early infancy in those who later go on to become obese, in comparison with healthy children [118]. A prospective study reported that bifidobacterial levels were significantly lower at 6 and 12 months, and specifically B. longum and B. breve, in children who at seven years of life displayed overweight, and the administration was able to reduce serum and liver triglyceride levels and to decrease hepatic adiposity [28]. Murri et al. observed a dysbiosis in the gut microbiota of diabetic children with respect to healthy children, with Bifidobacterium levels significantly decreased and negatively and significantly correlated with the plasma glucose level [119]. Therefore, the above results suggest that bifidobacterial species intervene and are determinant in the mentioned infant metabolic health risks [120]. These data point out at Bifidobacterium as a potential early life biomarker to assess the risk of overweight, obesity, and metabolic diseases associated in infants. 


\subsection{Maturation of the Immune System: Early Bifidobacterial Alterations Leading to Atopy}

Atopic diseases are the most common allergic conditions in children [121]. The atopy is characterized by an exaggerated IgE-mediated immune response to allergens that are usually innocuous and clinical manifestations include atopic dermatitis, allergic rhinitis, asthma, and food allergy. The term "atopic march" refers to the common fact that children who have one of these diseases are at high risk for further developing another one during childhood. The atopic march usually follows the order: atopic dermatitis > food allergy $>$ asthma $>$ atopic rhinitis [122]. Atopic diseases have increased in the last decades [121], especially in developed countries. Genetic and environmental factors have a crucial role in this condition; in this regard, the "hygiene hypothesis" [122] assumes that reduced early life exposure to factors contributing to the modulation and maturation of the immune system, as the contact and infection with different microbes could increase the risk of developing atopic diseases [123]. As it is known, the gut microbiota is one of the most important contributors to the development and maintenance of immune system functions. Some studies provide evidence that the cross-talk between the gut microbiota and the human immune system during early life is an important regulator for the later development of atopic and allergic diseases [124,125].

The genus Bifidobacterium plays a key role in this cross-talk. Several studies have reported that the intestinal microbial colonization pattern differs between non-allergic and allergic infants, with the latter group harboring a lower abundance of Bifidobacterium $[126,127]$. Later on, during childhood, the information is more controversial since some authors evidenced higher levels of the genus Bifidobacterium in allergic infants than in healthy children $[128,129]$. Lower diversity within the genus Bifidobacterium has been found in fecal samples of infants suffering cow's milk protein allergy [130]. The abundancies of some relevant species also differentiate the intestinal bifidobacterial populations of allergic from that of non-allergic children [130,131]. Fieten et al. identified six bacterial species in children with atopic dermatitis, whose profile discriminated individuals also presenting food allergy. Apart from E. coli, Faecalibacterium prausnitzii, and Akkermansia muciniphila, the other three species of this group in this study included B. breve, B. pseudocatenulatum, and B. adolescentis [124]. Toddlers with eczema were observed to harbor significantly lower counts of Bifidobacterium [132]. Moreover, Watanabe et al. found significantly lower levels of Bifidobacterium in adolescents with atopic dermatitis than in healthy control subjects; these levels were significantly lower in patients with severe skin symptoms than in those with mild skin symptoms [133].

Mechanisms linking the maturation of the immune system with early gut Bifidobacterium populations are not completely understood yet. However, recent articles shed light on this key aspect that associates the nascent microbiota with human health. Regulatory $\mathrm{T}$ cells (Treg) are $\mathrm{T}$ cell subsets that promote immunological tolerance and inhibit the development of allergy and autoimmunity. In a prospective study, Ruohtula et al., working with a birth-cohort of Estonian and Finnish children from 3 to 36 months of age, found a relationship between the maturation of the gut microbiota and blood Treg. In their children's cohorts, the maturation of circulating Treg cells involved a decrease in their frequency together with an increase in highly activated Treg, which was associated with the relative abundance of $B$. longum, followed by the colonization of butyrate-producing bacteria. The delay of this process in the Finnish children cohort comparatively increased the risk of IgE-mediated allergic sensitization with respect to the Estonian children [125]. Much of the suppressive potential of Treg cells depends on the long-term stable expression of FoxP3, a protein that acts as a key regulator transcription factor in activated Treg cells. The regulation of FoxP3 expression in Treg cells is a key step that occurs by complex signaling and epigenetic mechanisms [134], some of which involve bifidobacteria. The ability of some Bifidobacterium strains to increase, in vitro and in vivo, the expression of FoxP3 in Treg cells [135-137] mediated by interleukin-10 production [138] has been reported. 


\subsection{Brain Development and Social Behavior: New Target to Study the Significance of Bifidobacterium in Infant Health}

Infants exhibit different temperaments early in life and these behavioral traits could be critical in children's mental developmental pathways and can precede later psychopathology [139]. Some studies indicate that the gut microbiota play essential roles in the neurodevelopment and control of behavior [140]. We are still beginning to understand the role that bifidobacteria could play in neurological development and the temperament and behavior in early infancy. In two recent observational studies carried out in infants under one year of age, the authors reported traits, such as soothability and surgency (positive emotionality), as being associated with a higher relative abundance of the genus Bifidobacterium in the gut microbiota $[141,142]$. In addition, another study identified two bifidobacterial species related to negative emotionality (B. pseudocatenulatum) and regulation/orienting (B. pseudocatenulatum and B. catenulatum) temperamental domains, with both of these traits being marked by an enrichment of the genus Bifidobacterium [143]. In older children, with cohorts ranging from 2 to 9 years of age, altered levels of bifidobacteria have been described to be associated with neurodevelopmental disorders, autism, and children with a range of adverse experiences and caregiver stressors [144-146].

In an autism animal model, the impaired social interactions correlated with a gastrointestinal dysfunction and alterations on the bifidobacterial level, which were also associated with alterations of bile acid and tryptophan metabolism [147]. Luk et al. demonstrated the causal role of Bifidobacterium administered in the neonatal period in modifying the behavior of adult gnotobiotic mice. The altered behavioral pattern (abnormal memory, sociability, anxiety-like behavior, and motor performance) of adult mice's GF has been partly rescued when animals were neonatally colonized with conventional murine microbiota or with a consortium of four Bifidobacterium species known to be present at high levels in the commensal microbiota of human infants. The recognition memory was the trait more characteristically improved both in males and females. Conventionalized animals and those receiving the Bifidobacterium consortium presented anatomical differences in the central nervous system with respect to GF animals, which point to a homeostatic developmental balance of neural connections in the postnatal time period in re-colonized mice [148].

Bifidobacteria inhabiting the infant gut participate in the production of some metabolites that mediate gut-brain communication and are important in neurodevelopment. Some of them are tryptophan (an essential amino acid, present in proteins) and derived metabolites, which are important for intestinal and systemic homeostasis and have a positive impact on neurological functions. The predominant bifidobacterial species in the infant gut are able to produce indol-3-lactic acid (ILA), a tryptophan-derived metabolite, and, particularly, bifidobacteria from the infant gut produce more ILA than bifidobacteria present in the adult's intestine $[149,150]$. The induction of neurite outgrowth by ILA in a dose-dependent manner was demonstrated when this compound was added to cultures of PC12 cells, a rat adrenal pheochromocytoma lineage [151]. An anti-inflammatory effect of ILA produced by $B$. longum subsp. infantis in the presence of HMOs via activation of the aryl hydrogen receptor and nuclear factor erythroid 2-related factor 2 pathway was also observed [152]. On the other hand, sialic acid (N-Acetylneuraminic acid) is an essential compound for optimal brain development and cognition and takes part of oligosaccharides from human milk. Sialic acid is present in the brain of human beings at a higher concentration than in other mammals and it is also more abundant in the brain of breastfed babies than in those receiving formula [153-155]. The comprehension of the metabolism of sialylated oligosaccharides by bifidobacteria in the infant gut could help to improve our knowledge of the role of Bifidobacterium in the host-microbiota crosstalk and neurodevelopment processes during early infancy. 


\section{The Genus Bifidobacterium as a Probiotic for Infants}

Bifidobacteria is widely used as a probiotic for preventive and therapeutic purposes in neonates and infants. Probiotics are defined as live microorganisms, which when administered in adequate amounts confer a health benefit on the host [156]. Historically, the selection of probiotics was based on technological properties; however, nowadays, scientific evidence has demonstrated that the probiotics selection has to be done in a rational way, focused on specific targets and populations [157]. Given all the declarations cited before: high abundance on full-term, vaginally born, and breastfed infants; ability to metabolize HMOs; producers of SCFAs and other beneficial substances; and all the beneficial associations with a healthy status, among others, bifidobacteria are recognized as the ideal microorganisms for the development of probiotics for early life. In the next section, we expose different studies with probiotics both in neonatal animal models and clinical intervention studies with infants.

\subsection{Animal Models}

As already stated in this review, the natural establishment of the gut microbiota may be disturbed by several perinatal factors leading to a dysbiosis, associated with adverse health-related consequences in the neonatal stage or later in life [50]. The importance of correct timing of neonatal colonization becomes apparent in studies on the restoration of the microbiota in GF animals, with recovered normal function when realized in the period of early life but not in adulthood [158]. This crucial window of opportunity to shape the gut microbiota and consequently future health was carried out with several strains from the Bifidobacterium genus in animal models attempting to correct neonatal colonization and mucosal immunity, and to treat various infectious, allergic, neurodevelopmental, and metabolic conditions (Table 1). It should be noted that the vast majority of studies on the functionality and security of probiotics have been conducted in adult animals. Whereas, in the studies mentioned in Table 1, administration techniques specially adapted to the neonatal stage have been used, such as microbial transfer from dams to the offspring, treatment in the pregnancy period, and subsequent cohousing and breastfeeding periods. Alternatively, special cannulas were used, adapting the administrated volume to the animal's growth.

Several studies have demonstrated the potential role of B. breve (NCIMB8807, M-16V, AH1205) and B. longum AH1206 in improving the maturation of the intestinal immune system and promoting bifidobacterial colonization during early infancy [159-164]. An extensive transcriptomic regulation involving $\approx 4000$ genes significantly upregulated in the intestinal epithelial cells was observed after 3 days of treatment of two-week-old mice with $B$. breve UCC2003, including key genes linked with epithelial barrier development, and driving transcriptomic alteration [159]. Additionally, an influence on the correct development of the mucosal immunity in early life was observed, by an enhancement of the homing process of naive $T$ lymphocytes to the mesenteric lymph node, and the retention of activated lymphocytes in the intraepithelial compartment [160], reduced expression of inflammation-related genes in the colon [161], and an increased Treg proportion in the large intestine as well as enhanced gut immune and endocrine development in suckling mice $[162,163]$. 
Table 1. Examples of animal studies evidencing the impact of different Bifidobacterium strains in early life.

\begin{tabular}{|c|c|c|c|c|c|}
\hline Probiotic Strain & Dose & Target & $\begin{array}{l}\text { Animal Model (n)/Start at Postnatal } \\
\text { Age/Treatment }\end{array}$ & Clinical Outcome Results & Refs. \\
\hline B. breve M16V & $\begin{array}{l}1 \times 10^{9} \mathrm{CFU} / \mathrm{mL} \\
\text { drinking water }\end{array}$ & Caesarean section & $\begin{array}{l}\text { NIH Swiss mice }(\mathrm{n}=6-14) / 1 \mathrm{~d} \text { through } \\
\text { nursing dams / daily to } 21 \mathrm{~d}\end{array}$ & $\begin{array}{l}\text { Restored early life deficit in the Bifidobacterium spp. } \\
\text { abundance. Restored neonatal recognition abilities and } \\
\text { maternal attachment deficits }\end{array}$ & [102] \\
\hline B. breve UCC2003 & $2 \times 10^{6} \mathrm{CFU}$ & Intestinal barrier & $\begin{array}{l}\text { C57BL } / 6 \mathrm{~J} \text { mice }(\mathrm{n}=10) / 2 \mathrm{w} \text { by oral } \\
\text { gavage } / 3 \text { consecutive days }\end{array}$ & $\begin{array}{l}\text { Changes in neonatal intestinal epithelial cells } \\
\text { transcriptome } \\
\text { genes/pathways involved in epithelial barrier function }\end{array}$ & [159] \\
\hline B. breve $\mathrm{M}-16 \mathrm{~V}$ & $\approx 4 \times 10^{7} \mathrm{CFU}$ & Mucosal immunity & $\begin{array}{l}\text { Lewis rats }(\mathrm{n}=8) / 6 \mathrm{~d} \text { by oral gavage/daily } \\
\text { to } 18 \mathrm{~d}\end{array}$ & $\begin{array}{l}\text { Improved development of mucosal immunity in early life. } \\
\text { Enhanced intestinal IgA synthesis }\end{array}$ & [160] \\
\hline B. breve $\mathrm{M}-16 \mathrm{~V}$ & $5 \times 10^{8} \mathrm{CFU}$ & Mucosal immunity & $\begin{array}{c}\text { F344/Du rats }(\mathrm{n}=9-14) / 1 \mathrm{~d} \text { or } 21 \mathrm{~d} \text { by oral } \\
\text { gavage/daily } 2 \mathrm{w}\end{array}$ & $\begin{array}{l}\text { Reduced expression of inflammatory molecules during the } \\
\text { new-born period. Promoted tolerance by unregulated } \\
\text { expression of CD3 during the weaning period }\end{array}$ & [161] \\
\hline B. breve $\mathrm{M}-16 \mathrm{~V}$ & $\begin{array}{l}5 \times 10^{7} \mathrm{CFU}+20 \mathrm{mg} \\
\text { oligosaccharides }\end{array}$ & Mucosal immunity & $\begin{array}{l}\text { C57BL6 mice }(\mathrm{n}=7-14) / 6 \mathrm{~d} \text { or } 14 \mathrm{~d} \text { by oral } \\
\text { gavage/daily } 1 \mathrm{w}\end{array}$ & $\begin{array}{l}\text { Differentially expressed genes related to metabolism and } \\
\text { immune responses. Enhanced gut immune and endocrine } \\
\text { development in suckling mice }\end{array}$ & {$[162,163]$} \\
\hline $\begin{array}{l}\text { B. longum AH1206, B. breve } \\
\text { AH1205 }\end{array}$ & $2 \times 10^{9} \mathrm{CFU}$ & Mucosal immunity & $\begin{array}{c}\text { BALB } / \mathrm{c} \text { mice }(\mathrm{n}=8-10) / 1 \mathrm{~d} \text { by oral } \\
\text { gavage/daily } 6 \mathrm{w} \\
\text { BALB } / \mathrm{c} \text { and Swiss Webster GF mice } \\
(\mathrm{n}=8-10) / 6 \mathrm{w} \text { by oral gavage/daily } 4 \mathrm{w}\end{array}$ & $\begin{array}{l}\text { B. longum augmented T reg cell in neonatal and adult mice } \\
\text { B. breve enhanced the Peyer's Patch and the splenic T reg } \\
\text { cells when administered from birth }\end{array}$ & [164] \\
\hline B. infantis $\mathrm{n} / \mathrm{a}$ & $\mathrm{n} / \mathrm{a}$ & Oral tolerance & $\begin{array}{l}\text { BALB } / \mathrm{c} \text { mice }(\mathrm{n}=5) / \text { Neonatal or } \\
\text { adolescent by oral gavage/n/a } \\
\text { Oral challenge with OVA }\end{array}$ & $\begin{array}{l}\text { Bifidobacteria administered in neonates, but not at a later } \\
\text { age, restored the susceptibility of Th2 responses to oral } \\
\text { tolerance induction }\end{array}$ & [165] \\
\hline B. infantis $\mathrm{n} / \mathrm{a}$ & $\mathrm{n} / \mathrm{a}$ & Oral tolerance & $\begin{array}{l}\text { BALB/c mice }(\mathrm{n}=5) / \text { Dams by oral } \\
\text { gavage } / \mathrm{n} / \mathrm{a}\end{array}$ & Restored oral tolerance at similar levels of SPF mice & [166] \\
\hline B. bifidum TMC3115 & $1 \times 10^{9}$ CFUfreeze-dried & Allergy & $\begin{array}{c}\mathrm{BALB} / \mathrm{c} \text { mice }(\mathrm{n}=54) / 1 \mathrm{~d} \text { by oral } \\
\text { gavage } / 3 \mathrm{w} \\
\text { Intraperitoneal OVA challenge }\end{array}$ & $\begin{array}{l}\text { Minor increases in serum IgE levels induced by } \\
\text { OVA-challenge in adult stage and significantly higher } \\
\text { TNF- } \alpha \text { and IL-10 levels }\end{array}$ & [167] \\
\hline B. lactis BB- 12 & $1 \times 10^{9} \mathrm{CFU}$ & Allergy & $\begin{array}{l}\text { BALB } / \mathrm{c} \text { mice }(\mathrm{n}=6-9) / 1 \mathrm{~d} \text { by oral } \\
\text { gavage/every second day to } 8 \mathrm{w} \text { of life } \\
\text { Aerosolized OVA challenge }\end{array}$ & $\begin{array}{l}\text { Suppression of all aspects of the asthmatic phenotype: } \\
\text { airway reactivity, antigen-specific immunoglobulin E } \\
\text { production and pulmonary eosinophilia }\end{array}$ & [168] \\
\hline B. breve M16V & $\begin{array}{l}\text { Diet supplemented with } \\
1 \times 10^{6} \mathrm{CFU}\end{array}$ & Allergy & $\begin{array}{c}\text { BALB } / \mathrm{c} \text { mice }(\mathrm{n}=6-21) / \text { Pregnant and } \\
\text { nursing dams by diet } / 2 \mathrm{w} \\
\text { Exposition to air pollutant and aerosolized }\end{array}$ & $\begin{array}{c}\text { Maternal supplementation with bifidobacteria prevents } \\
\text { their offspring from allergic airway inflammation } \\
\text { accelerated by the prenatal exposure to an air } \\
\text { pollutant aerosol }\end{array}$ & [169] \\
\hline
\end{tabular}


Table 1. Cont.

\begin{tabular}{|c|c|c|c|c|c|}
\hline Probiotic Strain & Dose & Target & $\begin{array}{l}\text { Animal Model (n)/Start at Postnatal } \\
\text { Age/Treatment }\end{array}$ & Clinical Outcome Results & Refs. \\
\hline $\begin{array}{l}\text { B. longum subsp. longum } \\
\text { CCM7952 }\end{array}$ & $2 \times 10^{8} \mathrm{CFU}$ & Allergy & $\begin{array}{l}\text { BALB } / \mathrm{c} \text { mice }(\mathrm{n}=8-12) / \text { mono-associated } \\
\text { GF dams by oral gavage } / 1 \text { dose } \\
\text { Subcutaneously sensitization with } \\
\text { pollen allergen }\end{array}$ & $\begin{array}{l}\text { Neonatal mother-to-offspring mono-colonization with } \\
\text { bifidobacteria significantly reduced the development of } \\
\text { allergen-specific immune responses }\end{array}$ & [170] \\
\hline B. breve M16V & $\begin{array}{l}\text { Diet with FOS and } \\
2 \times 10^{9} \mathrm{CFU} / \mathrm{g}\end{array}$ & Allergy & $\begin{array}{l}\mathrm{C} 3 \mathrm{H} / \mathrm{HeOuJ} \text { mice }(\mathrm{n}=6-8) / 3 \mathrm{w} \text { by diet } / 9 \mathrm{~d} \\
\text { Intradermal whey-challenge }\end{array}$ & $\begin{array}{l}\text { Partial non-responsiveness to whey protein in mice orally } \\
\text { exposed to } \beta \text {-lactoglobulin-derived peptides }\end{array}$ & [171] \\
\hline B. breve M16V & $\begin{array}{l}\text { Diet with FOS/GOS and } \\
2 \times 10^{9} \mathrm{CFU} / \mathrm{g}\end{array}$ & Allergy & $\begin{array}{l}\mathrm{C} 3 \mathrm{H} / \mathrm{HeOuJ} \text { mice }(\mathrm{n}=6) / 3 \mathrm{w} \text { by diet } / 7 \mathrm{w} \\
\text { Intradermal whey-challenge }\end{array}$ & $\begin{array}{l}\text { Reduction of the allergic effector response in a murine } \\
\text { model of IgE-mediated hypersensitivity }\end{array}$ & [172] \\
\hline B. pseudolongum & $2 \times 10^{7}$ cells & Allergy & $\begin{array}{c}\text { BALB } / \mathrm{c} \text { mice }(\mathrm{n}=6) / 5 \mathrm{w} \text { by oral } \\
\text { gavage } / 2 \mathrm{w} \\
\text { DNFB-induced contact } \\
\text { hypersensitivity model }\end{array}$ & Reduction in the initial phase of the disease & [173] \\
\hline B. bifidum TMC3115 & $1 \times 10^{9} \mathrm{CFU}+$ antibiotics & Allergy & $\begin{array}{l}\text { BALB } / \mathrm{c} \text { mice }(\mathrm{n}=18) / 1 \mathrm{~d} \text { by oral } \\
\text { gavage } / 21 \mathrm{~d}\end{array}$ & $\begin{array}{l}\text { Significantly mitigated altered composition of the } \\
\text { intestinal microbiota, serum total IgE levels, and the } \\
\text { morphology and function of the intestinal epithelium }\end{array}$ & [174] \\
\hline $\begin{array}{l}\text { B. dentium ATCC27678, B. } \\
\text { infantis ATCC15697, B. breve } \\
\text { ATCC15698, B. bifidum } \\
\text { ATCC29521 }\end{array}$ & $1.1 \times 10^{9} \mathrm{CFU}$ & Neurodevelopment & $\begin{array}{l}\text { GF Swiss Webster mice }(\mathrm{n}=17) / 1 \mathrm{~d} \text { by oral } \\
\text { gavage/every other day to } 21 \mathrm{~d} \text {, when } \\
\text { weekly } 21 \mathrm{~d}-6 \mathrm{w}\end{array}$ & $\begin{array}{c}\text { Infant-type Bifidobacterium species mimics colonization } \\
\text { with a complex microbiota. Restored aspects of normal } \\
\text { anxiety-like behavior in a strongly sex-dependent manner. } \\
\text { Improved recognition memory }\end{array}$ & {$[148,175]$} \\
\hline $\begin{array}{l}\text { B. pseudocatenulatum } \\
\text { CECT7765 }\end{array}$ & $1 \times 10^{8} \mathrm{CFU}$ & Chronic stress & $\begin{array}{c}\text { C57Bl } / 6 \mathrm{~J} \mathrm{mice}(\mathrm{n}=18) / 2 \mathrm{~d} \text { by oral } \\
\text { gavage } / 3 \mathrm{w} \\
\text { Dairy maternal separation }\end{array}$ & $\begin{array}{l}\text { Attenuation of some aspects of the excessive stress } \\
\text { response of the HPA axis, particularly corticosterone } \\
\text { production at baseline and in response to acute stress in } \\
\text { adulthood }\end{array}$ & [176] \\
\hline B. infantis & $1 \times 10^{9} \mathrm{CFU}$ & Acute stress & $\begin{array}{l}\text { BALB } / \mathrm{c} \text { mice }(\mathrm{n}=18-24) / \text { mono-associated } \\
\text { GF dams by oral gavage } / 1 \text { dose }\end{array}$ & Reversed the exaggerated HPA stress response by GF mice & [177] \\
\hline B. infantis (Chr Hansen) & $\begin{array}{l}1 \times 10^{9} \\
\mathrm{CFU} / \text { freeze-dried }\end{array}$ & NEC & $\mathrm{SD}$ rats $(\mathrm{n}=24) / 1 \mathrm{~d}$ by oral gavage $/ 3 \mathrm{~d}$ & Reduction in the incidence of NEC & [178] \\
\hline B. infantis BB-02 & $3 \times 10^{6} \mathrm{CFU}$ & NEC & $\begin{array}{l}\text { C57BL } / 6 \text { mice }(\mathrm{n}=4-27) / 1 \mathrm{~d} \text { by oral } \\
\text { gavage } / 3 \mathrm{~d}\end{array}$ & $\begin{array}{l}\text { Attenuation of the increase in intestinal permeability and } \\
\text { decrease of the incidence of NEC }\end{array}$ & [179] \\
\hline Bifidobacterium sp. & $\begin{array}{l}1 \times 10^{10} \mathrm{CFU} / \mathrm{mL} \text { in } \\
\text { microcapsules }\end{array}$ & NEC & SPF SD rats $(\mathrm{n}=15) / 1 \mathrm{~d}$ by oral gavage $/ 3 \mathrm{~d}$ & Reduced NEC and intestinal damage severity. & [180] \\
\hline B. adolescentis & $1 \times 10^{8} \mathrm{CFU}$ & NEC & $\mathrm{SD}$ rats $(\mathrm{n}=15) / 1 \mathrm{~d}$ by oral gavage $/ 3 \mathrm{~d}$ & $\begin{array}{l}\text { Prevention of NEC and significantly decreased the rate of } \\
\text { NEC-like intestinal injury. }\end{array}$ & [181] \\
\hline
\end{tabular}


Table 1. Cont.

\begin{tabular}{|c|c|c|c|c|c|}
\hline Probiotic Strain & Dose & Target & $\begin{array}{c}\text { Animal Model (n)/Start at Postnatal } \\
\text { Age/Treatment }\end{array}$ & Clinical Outcome Results & Refs. \\
\hline $\begin{array}{l}\text { B. bifidum } \\
\text { OLB6378 }\end{array}$ & $5 \times 10^{6} \mathrm{CFU}$ & NEC & SD rats $(\mathrm{n}=30) / 1 \mathrm{~d}$ by oral gavage $/ 4 \mathrm{~d}$ & $\begin{array}{l}\text { Decreased the incidence of NEC and normalized the } \\
\text { expression and localization of tight junction and adherents } \\
\text { junction proteins in the ileum }\end{array}$ & [182] \\
\hline B. breve $\mathrm{M}-16 \mathrm{~V}$ & $6 \times 10^{7} \mathrm{CFU}$ & NEC & $\mathrm{SD}$ rats $(\mathrm{n}=17) / 1 \mathrm{~d}$ by oral gavage $/ 4 \mathrm{~d}$ & $\begin{array}{l}\text { Suppressed the increased expression of molecules related } \\
\text { to inflammation and barrier function that resulted from } \\
\text { NEC induction }\end{array}$ & [183] \\
\hline $\begin{array}{l}\text { B. longum subsp. infantis } \\
\text { ATCC15697 }\end{array}$ & $5 \times 10^{6} \mathrm{CFU}$ & NEC & SD rats $(\mathrm{n}=19) / 1 \mathrm{~d}$ by oral gavage $/ 4 \mathrm{~d}$ & $\begin{array}{l}\text { Significantly reduced associated inflammation and } \\
\text { incidence of NEC }\end{array}$ & [184] \\
\hline B. bifidum OLB6378 & $5 \times 10^{6} \mathrm{CFU}$ & NEC & SD rats $(n=30) / 1 \mathrm{~d}$ by oral gavage $/ 4 \mathrm{~d}$ & $\begin{array}{l}\text { Attenuation of induction of antimicrobial peptides and } \\
\text { NEC incidence }\end{array}$ & [185] \\
\hline $\begin{array}{l}\text { B. bifidum PM-A0218 and B. } \\
\text { longum PM-A0101 }\end{array}$ & $1 \times 10^{8} \mathrm{CFU}$ & NEC & SD rats $(\mathrm{n}=12) / 1 \mathrm{~d}$ by oral gavage $/ 3 \mathrm{~d}$ & Lower mortality & [186] \\
\hline Bifidobacterium sp. & $1 \times 10^{8} \mathrm{CFU} /$ daily & NEC & SD rats $(n=20) / 1 \mathrm{~d}$ by oral gavage $/ 3 \mathrm{~d}$ & $\begin{array}{l}\text { Decreased incidence and reduced the severity of NEC. } \\
\text { Inhibition of proinflammatory cytokine secretion and } \\
\text { improvement of intestinal barrier integrity. }\end{array}$ & [187] \\
\hline B. breve YIT4064 & $0.05 \%$ of diet, heat-killed & RV-induced diarrhea & $\begin{array}{c}\text { BALB / c mice }(\mathrm{n}=39) / \text { dams before and after } \\
\text { delivery by diet } / 9 \mathrm{w} \\
\text { /pups } 5 \text { d-old challenged with RV }\end{array}$ & $\begin{array}{l}\text { Pups born and nursed by dams fed with bifidobacteria } \\
\text { were more strongly protected against RV-induced } \\
\text { diarrhea. }\end{array}$ & [188] \\
\hline $\begin{array}{l}\text { B. bifidum ATCC15696 and B. } \\
\text { infantis ATCC15697 }\end{array}$ & $\begin{array}{l}0.75 \times 10^{8} \mathrm{CFU} / \mathrm{mL} \text { and } \\
0.75 \times 10^{8} \mathrm{CFU} / \mathrm{mL}\end{array}$ & RV-induced diarrhea & $\begin{array}{c}\text { BALB } / \mathrm{c} \text { mice }(\mathrm{n}=35) / 1 \mathrm{~d} \text { by oral gavage } / 7 \mathrm{w}: 1 \\
\text { dose } / \text { weekly } \\
\text { Pups } 5 \text { d-old challenged with RV }\end{array}$ & Significantly delayed and early resolution of diarrhea & [189] \\
\hline $\begin{array}{l}\text { B. longum SPM1206 and B. } \\
\text { longum SPM1205 }\end{array}$ & $\begin{array}{l}\text { Sonicated extract of } \\
2 \times 10^{8} \mathrm{CFU}\end{array}$ & RV-induced diarrhea & $\begin{array}{c}\mathrm{BALB} / \mathrm{c}(\mathrm{n}=\mathrm{n} / \mathrm{a}) / 12 \mathrm{~d} \text { by oral gavage } / 3 \mathrm{~d} \\
\text { Previous RV infection }\end{array}$ & $\begin{array}{l}\text { Inhibited rotavirus gene expression and replication with } \\
\text { significant increase of IFN- } \alpha \text { and IFN- } \beta \text { gene expression }\end{array}$ & [190] \\
\hline B. breve $\mathrm{M} 16 \mathrm{~V}$ & $2.5 \times 10^{9} \mathrm{CFU}+$ starch & Colitis & $\begin{array}{c}\text { F344 rats }(\mathrm{n}=6-12) / 21 \mathrm{~d} \text { by oral gavage } / 3 \mathrm{w} \\
\text { DSS-colitis }\end{array}$ & $\begin{array}{l}\text { Bifidobacteria modulates normal systemic T-cell immune } \\
\text { functions. Under inflammatory conditions ameliorates } \\
\text { DSS-induced colitis in weanling rats. }\end{array}$ & [191] \\
\hline B. animalis & $1 \times 10^{7} \mathrm{CFU}$ & Pathogen inhibition & $\begin{array}{c}\text { C57BL/ } 6 \text { athymic } b g / b g-n u / n u \text { and euthymic } \\
b g / b g-n u /+ \text { mice } \\
(\mathrm{n}=4-27) / \text { Mono-associated dams by oral and } \\
\text { anal inoculum } / 1 \text { dose } \\
\text { Infection with Candida albicans }\end{array}$ & Reduced incidence and severity & [192] \\
\hline B. infantis ATCC15697 & culture supernatant & Pathogen inhibition & $\begin{array}{l}\text { C57BL } / 6 \text { mice }(\mathrm{n}=23-26) / 1 \mathrm{~d} \text { by oral } \\
\text { gavage } / 8 \mathrm{~d} \\
\text { Infection with Cronobacter sakazakii }\end{array}$ & $\begin{array}{l}\text { Protection against } \text { C. sakazakii-induced intestinal } \\
\text { inflammation }\end{array}$ & [193] \\
\hline
\end{tabular}

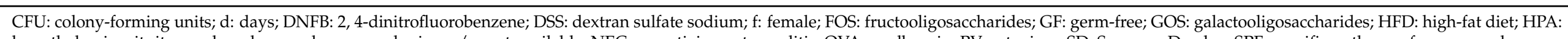
hypothalamic-pituitary-adrenal; m: male; n: sample size; n/a: not available; NEC: necrotizing enterocolitis; OVA: ovalbumin; RV: rotavirus; SD: Sprague-Dawley; SPF: specific-pathogen-free; w: weeks. 
The etiopathogenesis of allergic conditions is likely to be multifactorial, although alterations in gut colonization during early life are possible factors promoting abnormal postnatal immune maturation [194]. Studies conducted in an animal model of ovalbumin (OVA) sensitization in the neonatal stage with a previous treatment period with Bifidobacterium strains have demonstrated their potential to alleviate the risk of IgE-mediated allergies in adulthood, by exhibiting a minor increase in serum IgE levels induced by intraperitoneal-OVA challenge in the adult period and significantly higher IL-10 levels than in the control group [167]. Additionally, a positive effect of bifidobacteria treatment in models of airway inflammation was demonstrated by a reduction of allergic lung inflammation [168,169]. Regarding food allergy, it was suggested to occur due to defective oral tolerance in the neonatal stage [171], and various preclinical studies of a diet supplemented with prebiotic oligosaccharides and $B$. breve M-16V tested its capacity to satisfactorily prevent allergy development in an early life murine model of orally induced cow-milk allergy [171,172].

The neonatal stage is fundamental for proper neuronal development. Experimental studies suggest that the dysregulation of the microbiota-gut-brain axis in early life can impact brain development and behavior, resulting in altered cognitive and anxious phenotypes in adulthood [195]. In this way, several studies found that a mix of bifidobacteria species (B. longum subsp. infantis, B. breve, B. dentium, and B. bifidum) administrated to GF animals restored normal anxiety-like behavior and improved recognition memory $[148,175]$. Studying acute stress, the exaggerated hypothalamic-pituitary-adrenal (HPA) system stress response in GF mice was partly reversed by reconstitution of the microbiota with bifidobacteria [177]. In a maternal separation-induced stress model, the administration of a strain of B. pseudocatenulatum attenuated some aspects of the excessive HPA axis, particularly corticosterone production at baseline and in response to subsequent acute stress in adulthood [176].

Different models of experimental NEC were also subject to extensive investigation with bifidobacterial strains tested as probiotics. A protective effect of $B$. infantis (BB-02, ATCC15697), B. adolescentis (n/a), B. bifidum (OLB6378), B. breve M-16V, and the combination of B. bifidum PM-A0218 and B. longum PM-A0101 was reported on the intestine of newborn rats and mice, with a reduced NEC incidence and intestinal damage severity [178-187]. In rotavirus-associated diarrhea, bifidobacteria-treated animals were more strongly protected and presented an earlier resolution of the disease than non-treated animals [188-190].

\subsection{Clinical Trials}

The beneficial effects of bifidobacteria and the absence of negative effects following their oral administration have prompted their use in infant nutrition to support the development of a healthy microbiota and prevent diseases.

Some studies have evaluated the safety of probiotic formulas in early infancy $[196,197]$ and different studies have reported the benefits of probiotics in reducing the incidence and severity of gastrointestinal infections or constipation (Table 2). The amelioration of acute diarrhea in the pediatric population is one of the best-studied outcomes of probiotics use in general, and particularly of bifidobacteria. The main and consistent positive effects of bifidobacterial strains tested in clinical studies, both individually or in a cocktail of different probiotics, were a reduction of diarrhea duration and/or severity [198-203]. For example, different studies have observed that the administration of B. lactis BB-12 daily included in an infant formula or yogurt reduced diarrhea episodes, with respect to the placebo or other formulas not containing bifidobacteria [202,203]. Two trials investigated supplementation with several B. animalis subsp. lactis strains (doses not reported) in healthy infants with human immunodeficiency virus-infected mothers. While one trial reported significantly enhanced head growth and a trend toward increased weight gain compared to placebo [204], the other trial did not observe differences in these parameters between the B. lactis strain tested (CNCM I-3446) and placebo groups [205]. 
Secretory immunoglobulin A ( $\operatorname{Ig} \mathrm{A})$ is one of the most abundant immunoglobulins in the human body and is predominant in mucosal surfaces. sIgA plays a key role in the gastrointestinal defense mechanism against dietary and microbial antigens [206]. Therefore, several trials have been performed with the objective to enhance faecal sIgA through bifidobacterial administration. In a group of infants fed daily with a formula containing B. animalis subsp. lactis BB12, fecal sIgA was not affected by the treatment [207]; in contrast, a formula containing the same strain administered at a higher concentration to another group of infants significantly improved total sIgA and polio virus-specific IgA [208]. On the other hand, Taniuchi et al. observed that the administration of formulas supplemented with $B$. breve $\mathrm{M}-16 \mathrm{~V}$ to infants with cow's milk hypersensitivity and atopic dermatitis significantly increased the proportion of bifidobacteria in their fecal microbiota and improved their allergic symptoms [209]. Furthermore, the immunostimulation using probiotics was studied in a randomized double-blind placebo-controlled (RDBPC) trial carried out in infants under 5 years administered with a B. breve Yakult (BBG-01) in an oral inactivated cholera vaccine. Whereas this strain was well tolerated by children, a post vaccine immunostimulatory effect was not evident [210].

Table 2. Clinical studies and beneficial effects of Bifidobacterium strains on infants.

\begin{tabular}{|c|c|c|c|c|c|}
\hline Probiotic Strain & Dose & Aim & $\begin{array}{l}\text { Study Design/Study } \\
\text { Population }\end{array}$ & Clinical Outcome Results & Refs. \\
\hline $\begin{array}{l}\text { B. longum subsp. } \\
\text { infantis CECT7210 } \\
\text { (B. infantis IM1) }\end{array}$ & $\begin{array}{c}1 \times 10^{7} \mathrm{CFU} / \mathrm{g} \\
\text { formula }\end{array}$ & $\begin{array}{l}\text { To reduce diarrhea } \\
\text { incidence in healthy } \\
\text { term infants }\end{array}$ & $\begin{array}{c}\operatorname{RDBC}(12 \mathrm{w}) / \mathrm{n}=190 \\
(\text { age }<3 \mathrm{~m})\end{array}$ & $\begin{array}{c}\text { Reduction diarrhea } \\
\text { episodes, well tolerance } \\
\text { and lower constipation } \\
\text { prevalence }\end{array}$ & [201] \\
\hline $\begin{array}{l}\text { B. animalis subsp. } \\
\text { lactis BB-12 }\end{array}$ & $\begin{array}{l}1.5 \times 10^{8} \mathrm{CFU} / \mathrm{L} \\
\text { milk formula } \\
\text { supplemented }\end{array}$ & $\begin{array}{l}\text { To prevent acute } \\
\text { diarrhea }\end{array}$ & $\mathrm{RCT}(52 \mathrm{w}) / \mathrm{n}=90($ age $<8 \mathrm{~m})$ & $\begin{array}{c}\text { Reduced risk of diarrhea by } \\
\text { a factor of } 1.9 \\
\text { (range, } 1.33-2.6 \text { ) }\end{array}$ & [202] \\
\hline $\begin{array}{l}\text { B. animalis subsp. } \\
\text { lactis }\end{array}$ & $\begin{array}{l}3.6 \times 10^{7} \mathrm{CFU} / \mathrm{g} \\
\text { formula }\end{array}$ & $\begin{array}{l}\text { To determined } \\
\text { growth and stool } \\
\text { characteristics }\end{array}$ & $\begin{array}{l}\text { Double-blind study/ } \\
\quad \text { (up to } 4 \text {-m age) } \\
\mathrm{n}=88(\text { age } 6-10 \mathrm{~d})\end{array}$ & $\begin{array}{l}\text { Protection against } \\
\text { diarrheal illness }\end{array}$ & [203] \\
\hline $\begin{array}{l}\text { B. animalis subsp. } \\
\text { lactis }\end{array}$ & $\begin{array}{c}1 \times 10^{7}-10^{8} \mathrm{CFU} / \mathrm{g} \\
\text { formula }\end{array}$ & $\begin{array}{l}\text { To study the growth } \\
\text { of HIV-exposed } \\
\text { uninfected infants }\end{array}$ & $\begin{array}{l}\operatorname{RDBPC}(4 \mathrm{~m}) / \mathrm{n}=131 \\
(\text { age } 37-42 \mathrm{w})\end{array}$ & $\begin{array}{l}\text { Well growth, increased } \\
\text { head growth and a trend } \\
\text { towards increased } \\
\text { weight gain }\end{array}$ & [204] \\
\hline B. lactis CNCM I-3446 & $\begin{array}{l}67 \mathrm{kcal} / 100 \mathrm{~mL} \\
\text { formula } \\
\text { Ad libitum }\end{array}$ & $\begin{array}{l}\text { To study the growth } \\
\text { of HIV-exposed } \\
\text { uninfected infants }\end{array}$ & $\begin{array}{l}\operatorname{RDBPC}(6 \mathrm{~m}) / \mathrm{n}=132 \\
\quad(\text { age } 37-42 \mathrm{w})\end{array}$ & $\begin{array}{l}\text { Growth and metabolism in } \\
\text { HIV-negative infants fed } \\
\text { were not affected }\end{array}$ & [205] \\
\hline $\begin{array}{l}\text { B. animalis subsp. } \\
\text { lactis BB-12 }\end{array}$ & $\begin{array}{c}6 \times 10^{9} \mathrm{CFU} / 100 \mathrm{~mL} \\
\text { formula }\end{array}$ & $\begin{array}{l}\text { To study the effects } \\
\text { on the sIgA levels }\end{array}$ & $\begin{array}{l}\operatorname{RDBC}(32 \mathrm{w}) / \mathrm{n}=57 \\
\quad(\text { age } 0-32 \mathrm{w})\end{array}$ & $\begin{array}{l}\text { Trend towards higher fecal } \\
\text { sIgA levels—-statistically } \\
\text { significant at the age of } \\
16 \text { weeks }\end{array}$ & {$[207]$} \\
\hline $\begin{array}{l}\text { B. animalis subsp. } \\
\text { lactis BB-12 }\end{array}$ & $\begin{array}{c}1 \times 10^{6} \mathrm{CFU} / \mathrm{g} \\
\text { formula }\end{array}$ & $\begin{array}{l}\text { To study the effects } \\
\text { on intestinal } \\
\text { immunity and } \\
\text { inflammation }\end{array}$ & $\begin{array}{l}\text { Prospective RDBC }(6 \mathrm{w}) / \\
\mathrm{n}=172(\text { age } 6 \mathrm{w})\end{array}$ & Increment of fecal sIgA & [208] \\
\hline B. breve $\mathrm{M}-16 \mathrm{~V}$ & $\begin{array}{l}5 \times 10^{9} \mathrm{CFU} / \mathrm{g} \\
\text { cow's milk }\end{array}$ & $\begin{array}{l}\text { To elucidate the effect } \\
\text { on the intestinal } \\
\text { microbiota of infants } \\
\text { with cow's milk } \\
\text { hypersensitivity and } \\
\text { atopic dermatitis }\end{array}$ & $\begin{array}{c}\mathrm{RCT}(12 \mathrm{w}) / \mathrm{n}=17 \\
\text { (age } 2-5 \mathrm{y})\end{array}$ & $\begin{array}{l}\text { Improvement in the allergic } \\
\text { symptoms and increment of } \\
\text { bifidobacteria in feces }\end{array}$ & [209] \\
\hline $\begin{array}{l}\text { B. breve strain Yakult } \\
\text { (BBG-01) }\end{array}$ & $4 \times 10^{9} \mathrm{CFU} / \mathrm{g}$ & $\begin{array}{l}\text { To enhances the } \\
\text { immunogenicity of } \\
\text { oral cholera vaccine }\end{array}$ & $\begin{array}{c}\mathrm{RDBPC}(4 \mathrm{w}) / \mathrm{n}=128 \\
\text { (age } 2-5 \mathrm{y})\end{array}$ & $\begin{array}{c}\text { Well tolerance. Post } \\
\text { vaccinal } \\
\text { immunostimulatory effect } \\
\text { was not evident }\end{array}$ & [210] \\
\hline
\end{tabular}

CFU: colony-forming units; d: days; FCIC: functional chronic constipation; HIV: human immunodeficiency virus; m: months; RDBC: randomized doble-blind controlled clinical trial; RDBPC: randomized double-blind placebo-control trial; RCT: randomized controlled trial; w: weeks; y: years. 
As depicted before, premature birth is associated with high mortality rates and several serious complications later in life as well as aberrances in the gut microbiota composition. This highly vulnerable population could greatly benefit from probiotic administration; however, due to their critical immaturity, including an immunodeficient status, particular attention is paid in clinical trials to possible adverse events derived from the administration of these microbial products. A rational use of bifidobacteria given their safety and beneficial effects on early gut microbiota establishment makes them an ideal probiotic option. Several trials have been performed in premature babies with different bifidobacterial strains (Table 3). A trial showed that a formula containing B. animalis subsp. lactis BB-12 administered daily to premature babies for 1 month improved their gut microbiota composition [211], as well as the combination of B. bifidum-Lactobacillus acidophilus in another cohort of preterm babies [212]. A prospective randomized clinical study with VLBW preterm babies examined the effect of B. breve YIT4010 supplementation for four weeks [213]. During the administration, the volume of aspirated gas from the stomach was significantly reduced, indicating reduced severity of NEC. The children colonized by B. breve YIT4010 received fewer analgesic doses and showed greater weight gain during the four weeks after administration [213]. Similarly, the administration of the same strain (BB-12) to preterm infants in increasing doses reduced intestinal permeability and increased head growth during the first 30 days of life [214]. By contrast, in another clinical trial, the administration of $B$. animalis subsp. lactis BB-12 to VLBW infants did not reduce the incidence of nosocomial infections [215]. A large trial carried out in VLBW infants in five different NICUs compared the effect of the administration of a B. animalis subsp. lactis strain, a prebiotic, and a mix of both (synbiotic) for a maximum of 8 weeks after birth and observed that the NEC incidence was significantly reduced in the B. animalis subsp. Lactis-administered group. Furthermore, the administration of this probiotic also showed significantly lower rates of nosocomial sepsis and mortality, shorter time to full enteral feeding, and shorter stays in the NICUs [216]. Patole et al. performed a retrospective cohort study in preterm children over two years, and observed a significant reduction of NEC incidence after the introduction of a daily supplement containing B. breve M-16V [217]. This effect could be linked to the anti-inflammatory properties of this $B$. breve strain demonstrated in a trial carried out with a group of preterm newborns that received this microorganism daily in two doses, for which increased serum levels of TGF- $\beta$ compared to placebo-fed infants were detected [218]. However, another multicenter trial, including 24 hospitals analyzing the effect of a daily administration of either a formula containing B. breve BBG-001 or placebo in a large number of preterm infants within the first $48 \mathrm{~h}$ of birth, did not find statistically significant effects on NEC incidence, sepsis, or mortality rate among groups [219]. Additionally, the early administration of a B. breve strain also had a positive effect on the gut microbiota of low-birth-weight (LBW) babies [220], prevented NEC and infection in extremely-low-birth-weight and VLBW babies [221,222], and reduced the production of butyric acid [223]. In a retrospective analysis of data on small gestational age versus appropriate for gestational age infants for three years, the outcomes between both preterm infants after $B$. breve $\mathrm{M}-16 \mathrm{~V}$ administration showed a trend toward a reduction of NEC and LOS in both groups [224]. Additionally, the bacterial cocktail of B. bifidum-L. acidophilus and B. breve-Lactobacillus casei has been successful in the reduction of NEC incidence $[225,226]$. Meanwhile, the administration of $B$. breve $\mathrm{M}-16 \mathrm{~V}$ promotes bifidobacteria colonization in fecal samples without adverse effects $[227,228]$. A strain of B. bifidum in VLBW infants accelerated the establishment of enteral feeding without increasing morbidity, with a significant decrease in LOS [229], and a pilot study's administration of B. infantis to term babies scheduled for heart surgery within the first few weeks of life did not significantly alter the fecal microbiota and changes in plasma cytokines were found to be inconsistent [230]. 
Table 3. Clinical studies and beneficial effects of Bifidobacterium strains on preterm infants.

\begin{tabular}{|c|c|c|c|c|c|}
\hline Probiotic Strain & Dose & Aim & Study Design/STUDY Population & Clinical Outcome Results & Refs. \\
\hline B. lactis BB-12 & $\begin{array}{l}2.9 \times 10^{9} \mathrm{CFU} / \mathrm{g} \\
\text { formula }\end{array}$ & $\begin{array}{l}\text { To reduce the potentially } \\
\text { harmful bacteria }\end{array}$ & $\operatorname{RDBPC}(1 \mathrm{~m}) / \mathrm{n}=69(\mathrm{GA}<37 \mathrm{w})$ & $\begin{array}{l}\text { Bifidobacteria increment. } \\
\text { Enterobacteria and clostridia } \\
\text { reduction. }\end{array}$ & [211] \\
\hline B. bifidum and L. acidophilus & $2.0 \times 10^{9} \mathrm{CFU} /$ twice day & $\begin{array}{l}\text { To explore the gut microbiota } \\
\text { composition and fecal } \\
\text { metabolome }\end{array}$ & $\begin{array}{l}\text { Observational study }(99 \mathrm{~d}) / \mathrm{n}=101 \\
(\mathrm{GA}<34 \mathrm{w})\end{array}$ & $\begin{array}{l}\text { Predominance of Bifidobacterium } \\
\text { and a lower abundance of } \\
\text { pathobionts. Higher fecal acetate } \\
\text { and lactate }\end{array}$ & [212] \\
\hline B. lactis $\mathrm{BB}-12$ & $2.0 \times 10^{7} \mathrm{CFU} / \mathrm{g}$ of dry milk & $\begin{array}{l}\text { To determine the effect on } \\
\text { intestinal permeability, } \\
\text { somatic growth, tolerance, } \\
\text { rates of sepsis and NEC }\end{array}$ & $\begin{array}{l}\text { Prospective randomized case-control } \\
\text { study }(30 \mathrm{~d}) / \mathrm{n}=41 \text { (GA } 27-37 \mathrm{w})\end{array}$ & $\begin{array}{l}\text { Reduced intestinal permeability } \\
\text { and increased head growth }\end{array}$ & [214] \\
\hline B. lactis $\mathrm{BB}-12$ & $1.2 \times 10^{10} \mathrm{CFU} / \mathrm{kg} /$ day & $\begin{array}{l}\text { To reduce the incidence of } \\
\text { nosocomial infections }\end{array}$ & $\begin{array}{c}\text { RCT }(6 \mathrm{w}) / \mathrm{n}=183 \\
(\mathrm{GA} 23-26 \text { and } 27-29 \mathrm{w})\end{array}$ & $\begin{array}{l}\text { The incidence was not reduced, } \\
\text { and no adverse effect was observed }\end{array}$ & [215] \\
\hline B. breve $\mathrm{M}-16 \mathrm{~V}$ & $3.0 \times 10^{9} \mathrm{CFU} /$ day & $\begin{array}{l}\text { To reduce the incidence of } \\
\text { NEC }\end{array}$ & $\begin{array}{l}\text { Retrospective cohort study (over the } \\
\text { course of } 2 \mathrm{y}) / \mathrm{n}=1755(\mathrm{GA}<34 \mathrm{w})\end{array}$ & $\begin{array}{c}\text { Decrease incidence of NEC } \geq \text { Stage } \\
\text { II or all-cause mortality }\end{array}$ & [217] \\
\hline B. breve $\mathrm{M}-16 \mathrm{~V}$ & $\begin{array}{c}1.0 \times 10^{9} \text { cells } / 0.5 \mathrm{~mL} / \mathrm{twice} \\
\text { a day }\end{array}$ & $\begin{array}{l}\text { To examine the effect on the } \\
\text { immunologic system in } \\
\text { relation to TGF- } \beta\end{array}$ & $\begin{array}{l}\mathrm{RCT}(59 \pm 29.3 \mathrm{~d}) / \mathrm{n}=19 \\
\quad(\mathrm{GA} 31.3 \pm 3.16 \mathrm{w})\end{array}$ & $\begin{array}{c}\text { Up-regulation of TGF- } \beta 1 \text { signaling } \\
\text { and attenuation of inflammatory } \\
\text { and allergic reactions }\end{array}$ & [218] \\
\hline B. breve BBG-001 & $8.2-9.2 \times 10^{10} \mathrm{CFU}$ & $\begin{array}{l}\text { To reduce NEC, LOS, and } \\
\text { death in preterm infants }\end{array}$ & $\begin{array}{c}\text { Multicenter blinded randomized } \\
\text { controlled phase } 3 \text { study }(36 \mathrm{w}) / \mathrm{n}=1315 \\
(\text { GA } 23-30 \mathrm{w})\end{array}$ & $\begin{array}{l}\text { There was no evidence of benefit } \\
\text { for this intervention in this } \\
\text { population }\end{array}$ & [219] \\
\hline B. breve & $1.6 \times 10^{8} \mathrm{CFU} /$ twice a day & $\begin{array}{c}\text { To evaluate positive effect on } \\
\text { gut microbiota }\end{array}$ & $\mathrm{RCT}(7 \mathrm{w}) / \mathrm{n}=30(\mathrm{GA} 27.8-37.6 \mathrm{w})$ & $\begin{array}{l}\text { Promotion on Bifidobacterium } \\
\text { colonization and normal gut } \\
\text { microbiota development }\end{array}$ & [220] \\
\hline B. breve $\mathrm{M}-16 \mathrm{~V}$ & $1.10 \times 10^{9} \mathrm{CFU} /$ day & To prevent NEC and infection & $\begin{array}{c}\text { Control study }(4 \mathrm{y}) / \mathrm{n}=338 \\
(\text { GA 27-36 w) }\end{array}$ & NEC and infection were prevented & [221] \\
\hline
\end{tabular}


Table 3. Cont.

\begin{tabular}{|c|c|c|c|c|c|}
\hline Probiotic Strain & Dose & Aim & Study Design/STUDY Population & Clinical Outcome Results & Refs. \\
\hline B. breve $\mathrm{M}-16 \mathrm{~V}$ & $1 \times 10^{9} \mathrm{CFU} / \mathrm{g}$ & $\begin{array}{l}\text { To prevent infection and } \\
\text { sepsis }\end{array}$ & $\begin{aligned} \operatorname{RCT} & (91.8 \pm 54.1 \mathrm{~d}) / \mathrm{n}=108 \\
& (\mathrm{GA} 28.1 \pm 2.8 \mathrm{w})\end{aligned}$ & $\begin{array}{l}\text { Development of infections and } \\
\text { sepsis were significantly lower }\end{array}$ & [222] \\
\hline B. breve $\mathrm{M}-16 \mathrm{~V}$ & $\begin{array}{c}1.6 \times 10^{8} \text { CFU twice daily } \\
\text { until discharge }\end{array}$ & $\begin{array}{l}\text { To determine the effects on } \\
\text { fecal lactic acid and SCFAs }\end{array}$ & $\mathrm{RCT}(4 \mathrm{w}) / \mathrm{n}=66(\mathrm{GA} 23-36 \mathrm{w})$ & Butyric acid was reduced & [223] \\
\hline B. breve $\mathrm{M}-16 \mathrm{~V}$ & $3 \times 10^{9} \mathrm{CFU} /$ day & $\begin{array}{c}\text { To compare clinical outcomes } \\
\text { between preterm SGA vs. } \\
\text { AGA infants after probiotic } \\
\text { administration }\end{array}$ & $\begin{array}{l}\text { Retrospective cohort study (3 y)/ } \\
\qquad \mathrm{n}=1380(\mathrm{GA}<34 \mathrm{w})\end{array}$ & $\begin{array}{l}\text { NEC, LOS, and all-cause mortality } \\
\text { rates were similar in preterm SGA } \\
\text { vs AGA infants }\end{array}$ & [224] \\
\hline B. bifidum and L. acidophilus & $\begin{array}{c}1 \times 10^{9} \mathrm{CFU} / 125 \mathrm{mg} / \mathrm{kg} \\
\text { twice daily }\end{array}$ & To prevent NEC & $\begin{array}{l}\text { Prospective, blinded, randomized, } \\
\text { multicenter controlled }(6 \mathrm{w}) / \mathrm{n}=580 \\
(\mathrm{GA}<34 \mathrm{w} \text { and }<1500 \mathrm{~g})\end{array}$ & $\begin{array}{l}\text { Incidence reduction of death } \\
\text { or NEC }\end{array}$ & [225] \\
\hline B. breve and L. casei & $3.5 \times 10^{7}$ to $3.5 \times 10^{9} \mathrm{CFU}$ & $\begin{array}{l}\text { To prevent the occurrence of } \\
\text { NEC stage } \geq 2 \text { by criteria } \\
\text { of Bell }\end{array}$ & $\mathrm{RDBC}(30 \mathrm{~d}) / \mathrm{n}=231(\mathrm{GA} 29.5 \pm 2.5 \mathrm{w})$ & $\begin{array}{l}\text { Reduced the occurrence of NEC } \\
\qquad(\text { Bell's stage } \geq 2 \text { ) }\end{array}$ & [226] \\
\hline B. breve $\mathrm{M}-16 \mathrm{~V}$ & $5 \times 10^{8} \mathrm{CFU} /$ day & $\begin{array}{l}\text { To investigate the effects on } \\
\text { the intestinal microbiota }\end{array}$ & $\mathrm{RCT}(6 \mathrm{w}) / \mathrm{n}=46(\mathrm{GA} 29.9 \pm 2.3 \mathrm{w})$ & $\begin{array}{l}\text { Promotion of bifidobacteria } \\
\text { colonization and the formation of a } \\
\text { healthy microbiota }\end{array}$ & [227] \\
\hline B. breve $\mathrm{M}-16 \mathrm{~V}$ & $3 \times 10^{9} \mathrm{CFU} /$ day & $\begin{array}{c}\text { To increase fecal B. breve } \\
\text { counts without } \\
\text { adverse effects }\end{array}$ & $\operatorname{RDBPC}(6 \mathrm{w}) / \mathrm{n}=159(\mathrm{GA}<33 \mathrm{w})$ & $\begin{array}{l}\text { Increased the proportion of } \\
\text { neonates with detectable } B \text {. breve }\end{array}$ & [228] \\
\hline B. bifidum OLB6378 & $\begin{array}{c}2.5 \times 10^{9} \text { viable } \\
\text { cells } / 500 \mathrm{mg} / \text { twice a day }\end{array}$ & $\begin{array}{c}\text { To evaluate the benefit on } \\
\text { enteral feeding }\end{array}$ & $\begin{array}{l}\text { RCT study }(21 \mathrm{~d}) / \mathrm{n}=585 \\
\quad(\mathrm{GA} 28.6 \pm 2.9 \mathrm{w})\end{array}$ & $\begin{array}{l}\text { Acceleration of the establishment } \\
\text { of enteral feeding after birth }\end{array}$ & [229] \\
\hline $\begin{array}{l}\text { B. longum subsp. infantis } \\
\text { ATCC } 15697\end{array}$ & $\begin{array}{l}4.2 \times 10^{9} \mathrm{CFU} / \text { two } \\
\text { times daily }\end{array}$ & $\begin{array}{l}\text { To investigate the impact on } \\
\text { the fecal microbiota and } \\
\text { plasma cytokines in neonates } \\
\text { with congenital heart disease }\end{array}$ & $\mathrm{RCT}($ for $8 \mathrm{w}) / \mathrm{n}=16(\mathrm{GA} 38.4 \pm 1.2 \mathrm{w})$ & $\begin{array}{l}\text { There was no significant alteration } \\
\text { in the gut microbiota and plasma } \\
\text { interleukin (IL)10, interferon (IFN) } \\
\text { y and IL1 } \beta \text { levels were higher }\end{array}$ & [230] \\
\hline
\end{tabular}


In short, most studies carried out until present have shown positive effects of bifidobacteria supplementation in premature infants on the severity and incidence of NEC and infections. Therefore, the treatment of preterm and VLBW infants with bifidobacteria is an alternative therapy that could help on the prevention or treatment of NEC. Despite this, the selection of the appropriate strain and more clinical trials are needed to identify the most effective bifidobacterial probiotics and their potential mechanism of action.

\section{Conclusions}

This review has outlined the pivotal role of the bifidobacteria on the neonatal health. The early gut microbiota is very unstable and is highly susceptible to being affected by external factors, this being especially relevant for the genus Bifidobacterium members. Reduced levels of bifidobacteria have been observed in different perinatal circumstances, such as in premature or C-section-delivered babies or after antibiotic treatment, but also in individuals later developing different metabolic, immune, and neurodevelopmental diseases. Nowadays, we are starting to understand that these aberrances not only exist at genus level but also at specific bifidobacterial species levels. The cited considerations, together with the large trajectory and safe use as probiotics, make them ideal candidates to be used in a preventive or therapeutic way in early life when the correct gut microbiota establishment is jeopardized. Several Bifidobacterium strains have been studied in preclinical models with encouraging results at enteric and systemic levels. In recent years, a substantial number of bifidobacterial strains have already been tested in clinical trials with promising results, especially in premature babies and in diarrheal processes. The evidence discussed in this review suggests a putative causal role of bifidobacteria in some health alterations or diseases and opens the debate to use them as a marker of disrupted homeostasis in early life. In the coming years, novel scientific discoveries will become true and allow a ful understanding of the role of the bifidobacteria function on early human health with important translational deliverables to medical environments and functional food industries.

Author Contributions: Writing—original draft preparation, S.S., A.M.N., G.M.A.-J., N.S., C.G.d.1.R.-G., M.G., S.A.; writing-review and editing, M.G., S.A. All authors have read and agreed to the published version of the manuscript.

Funding: This review has received funding from the Project AGL2017-83653R funded by the Spanish Ministerio de Ciencia, Innovación y Universidades (MCIU)/Agencia Estatal de Investigación (AEI/10.13039/501100011033/) and FEDER "Una manera de hacer Europa". S.A. was the recipient of a postdoctoral Juan de la Cierva-Incorporación Contract (Ref. IJCI-2017-32156) funded by MCIU/AEI/10.13039/501100011033.

Institutional Review Board Statement: Not applicable.

Informed Consent Statement: Not applicable.

Data Availability Statement: Not applicable.

Conflicts of Interest: The authors declare no conflict of interest.

\section{References}

1. Milani, C.; Duranti, S.; Bottacini, F.; Casey, E.; Turroni, F.; Mahony, J.; Belzer, C.; Palacio, S.D.; Montes, S.A.; Mancabelli, L.; et al. The first microbial colonizers of the human gut: Composition, activities, and health implications of the infant gut microbiota. Microbiol. Mol. Biol. Rev. 2017, 81, e00036-17. [CrossRef]

2. Sommer, F.; Bäckhed, F. The gut microbiota-Masters of host development and physiology. Nat. Rev. Microbiol. 2013, 11, 227-238. [CrossRef]

3. Tissier, H. Recherchers Sur La Flora Intestinale Normale Et Pathologique Du Nourisson. Ph.D. Thesis, University of Paris, Paris, France, 1900.

4. Scardovi, V. Genus Bifidobacterium Orla-Jensen 1924, 472al; Williams and Wilkins: Baltimore, MD, USA, 1986.

5. Alessandri, G.; van Sinderen, D.; Ventura, M. The genus Bifidobacterium: From genomics to functionality of an important component of the mammalian gut microbiota. Comput. Struct. Biotechnol. J. 2021, 19, 1472-1487. [CrossRef] 
6. Ahn, J.B.; Hwang, H.J.; Park, J.H. Physiological responses of oxygen-tolerant anaerobic bifidobacterium longum under oxygen. J. Microbiol. Biotechnol. 2001, 11, 443-451.

7. Mattarelli, B. The Family Bifidobacteriaceae, 3rd ed.; Springer: New York, NY, USA, 2006.

8. Picard, C.; Fioramonti, J.; Francois, A.; Robinson, T.; Neant, F.; Matuchansky, C. Review article: Bifidobacteria as probiotic agents-physiological effects and clinical benefits. Aliment. Pharmacol. Ther. 2005, 22, 495-512. [CrossRef] [PubMed]

9. Quigley, E.M.M. Chapter 12-Bifidobacteria as probiotic organisms: An introduction. In The Microbiota in Gastrointestinal Pathophysiology; Floch, M.H., Ringel, Y., Allan Walker, W., Eds.; Academic Press: Boston, MA, USA, 2017; pp. $125-126$.

10. Arboleya, S.; Watkins, C.; Stanton, C.; Ross, R.P. Gut bifidobacteria populations in human health and aging. Front. Microbiol. 2016, 7, 1204. [CrossRef] [PubMed]

11. Lewis, Z.T.; Mills, D.A. Differential Establishment of Bifidobacteria in the Breastfed Infant Gut; Karger, A.G., Ed.; Karger Publishers: Basel, Switzerland, 2017; pp. 149-160.

12. Bäckhed, F.; Roswall, J.; Peng, Y.; Feng, Q.; Jia, H.; Kovatcheva-Datchary, P.; Li, Y.; Xia, Y.; Xie, H.; Zhong, H.; et al. Dynamics and Stabilization of the Human Gut Microbiome during the First Year of Life. Cell Host Microbe 2015, 17, 690-703. [CrossRef]

13. Vaiserman, A.M.; Koliada, A.; Marotta, F. Gut microbiota: A player in aging and a target for anti-aging intervention. Ageing Res. Rev. 2017, 35, 36-45. [CrossRef] [PubMed]

14. Salazar, N.; Arboleya, S.; Fernández-Navarro, T.; Reyes-Gavilán, C.G.D.L.; Gonzalez, S.; Gueimonde, M. Age-Associated Changes in Gut Microbiota and Dietary Components Related with the Immune System in Adulthood and Old Age: A Cross-Sectional Study. Nutrients 2019, 11, 1765. [CrossRef] [PubMed]

15. Gueimonde, M.; Ouwehand, A.; Pitkälä, K.; Strandberg, T.; Finne-Soveri, H.; Salminen, S. Fecal Bifidobacterium Levels in Elderly Nursing Home Patients. Biosci. Microflora 2010, 29, 111-113. [CrossRef]

16. Karlsson, C.L.J.; Molin, G.; Cilio, C.M.; Ahrné, S. The Pioneer Gut Microbiota in Human Neonates Vaginally Born at Term-A Pilot Study. Pediatr. Res. 2011, 70, 282-286. [CrossRef]

17. Aggett, P.J.; Agostoni, C.; Axelsson, I.; Edwards, C.A.; Goulet, O.; Hernell, O.; Koletzko, B.; Lafeber, H.N.; Micheli, J.-L.; Michaelsen, K.F.; et al. Nondigestible Carbohydrates in the Diets of Infants and Young Children: A Commentary by the ESPGHAN Committee on Nutrition. J. Pediatr. Gastroenterol. Nutr. 2003, 36, 329-337. [CrossRef] [PubMed]

18. Wang, M.; Li, M.; Wu, S.; Lebrilla, C.B.; Chapkin, R.; Ivanov, I.; Donovan, S.M. Fecal Microbiota Composition of Breast-Fed Infants Is Correlated With Human Milk Oligosaccharides Consumed. J. Pediatr. Gastroenterol. Nutr. 2015, 60, 825-833. [CrossRef]

19. Solís, G.; Reyes-Gavilan, C.D.L.; Fernández, N.; Margolles, A.; Gueimonde, M. Establishment and development of lactic acid bacteria and bifidobacteria microbiota in breast-milk and the infant gut. Anaerobe 2010, 16, 307-310. [CrossRef] [PubMed]

20. Martín, R.; Langa, S.; Reviriego, C.; Jiménez, E.; Marín, M.L.; Xaus, J.; Fernández, L.; Rodríguez, J.M. Human milk is a source of lactic acid bacteria for the infant gut. J. Pediatr. 2003, 143, 754-758. [CrossRef]

21. Collado, M.; Delgado, S.; Maldonado, A.; Rodríguez, J. Assessment of the bacterial diversity of breast milk of healthy women by quantitative real-time PCR. Lett. Appl. Microbiol. 2009, 48, 523-528. [CrossRef]

22. Gueimonde, M.; Laitinen, K.; Salminen, S.; Isolauri, E. Breast Milk: A Source of Bifidobacteria for Infant Gut Development and Maturation? Neonatology 2007, 92, 64-66. [CrossRef] [PubMed]

23. Lyons, K.E.; Ryan, C.A.; Dempsey, E.M.; Ross, R.P.; Stanton, C. Breast Milk, a Source of Beneficial Microbes and Associated Benefits for Infant Health. Nutrients 2020, 12, 1039. [CrossRef]

24. Henrick, B.M.; Rodriguez, L.; Lakshmikanth, T.; Pou, C.; Henckel, E.; Arzoomand, A.; Olin, A.; Wang, J.; Mikes, J.; Tan, Z.; et al. Bifidobacteria-mediated immune system imprinting early in life. Cell 2021, 184, 3884-3898. [CrossRef]

25. Victora, C.G.; Bahl, R.; Barros, A.J.D.; França, G.V.A.; Horton, S.; Krasevec, J.; Murch, S.; Sankar, M.J.; Walker, N.; Rollins, N.C.; et al. Breastfeeding in the 21st century: Epidemiology, mechanisms, and lifelong effect. Lancet 2016, 387, 475-490. [CrossRef]

26. Lapidaire, W.; Lucas, A.; Clayden, J.D.; Clark, C.; Fewtrell, M.S. Human milk feeding and cognitive outcome in preterm infants: The role of infection and NEC reduction. Pediatr. Res. 2021, 1-8. [CrossRef]

27. Tojo, R.; Suárez, A.; Clemente, M.G.; de los Reyes-Gavilán, C.G.; Margolles, A.; Gueimonde, M.; Ruas-Madiedo, P. Intestinal microbiota in health and disease: Role of bifidobacteria in gut homeostasis. World J. Gastroenterol. 2014, 20, 15163-15176. [CrossRef]

28. Kalliomäki, M.; Collado, M.C.; Salminen, S.; Isolauri, E. Early differences in fecal microbiota composition in children may predict overweight. Am. J. Clin. Nutr. 2008, 87, 534-538. [CrossRef] [PubMed]

29. Fujimura, K.E.; Sitarik, A.R.; Havstad, S.; Lin, D.L.; LeVan, S.; Fadrosh, D.; Panzer, A.R.; LaMere, B.; Rackaityte, E.; Lukacs, N.W.; et al. Neonatal gut microbiota associates with childhood multisensitized atopy and T cell differentiation. Nat. Med. 2016, 22, 1187-1191. [CrossRef] [PubMed]

30. De Palma, G.; Capilla, A.; Nova, E.; Castillejo, G.; Varea, V.; Pozo, T.; Garrote, J.A.; Polanco, I.; López, A.; Ribes-Koninckx, C.; et al. Influence of Milk-Feeding Type and Genetic Risk of Developing Coeliac Disease on Intestinal Microbiota of Infants: The PROFICEL Study. PLoS ONE 2012, 7, e30791. [CrossRef] [PubMed]

31. Ouwehand, A.; Isolauri, E.; He, F.; Hashimoto, H.; Benno, Y.; Salminen, S. Differences in Bifidobacterium flora composition in allergic and healthy infants. J. Allergy Clin. Immunol. 2001, 108, 144-145. [CrossRef] [PubMed] 
32. Saturio, S.; Nogacka, A.; Suárez, M.; Fernández, N.; Mantecón, L.; Mancabelli, L.; Milani, C.; Ventura, M.; Reyes-Gavilán, C.D.L.; Solís, G.; et al. Early-Life Development of the Bifidobacterial Community in the Infant Gut. Int. J. Mol. Sci. 2021, $22,3382$. [CrossRef]

33. Introduction of a Qualified Presumption of Safety (QPS) approach for assessment of selected microorganisms referred to EFSA-Opinion of the Scientific Committee. Eur. Food Saf. Auth. J. 2007, 5. [CrossRef]

34. Gueimonde, M.; Arboleya, S. Resistance of Bifidobacteria toward Antibiotics; Springer: Berlin, Gemany, 2021; Volume 2278, pp. 195-208. [CrossRef]

35. Turroni, F.; Marchesi, J.R.; Foroni, E.; Gueimonde, M.; Shanahan, F.; Margolles, A.; van Sinderen, D.; Ventura, M. Microbiomic analysis of the bifidobacterial population in the human distal gut. Multidiscip. J. Microb. Ecol. 2009, 3, 745-751. [CrossRef]

36. Masco, L.; Huys, G.; De Brandt, E.; Temmerman, R.; Swings, J. Culture-dependent and culture-independent qualitative analysis of probiotic products claimed to contain bifidobacteria. Int. J. Food Microbiol. 2005, 102, 221-230. [CrossRef]

37. Turroni, F.; Foroni, E.; Pizzetti, P.; Giubellini, V.; Ribbera, A.; Merusi, P.; Cagnasso, P.; Bizzarri, B.; De'Angelis, G.L.; Shanahan, F.; et al. Exploring the Diversity of the Bifidobacterial Population in the Human Intestinal Tract. Appl. Environ. Microbiol. 2009, 75, 1534-1545. [CrossRef] [PubMed]

38. Ishikawa, E.; Matsuki, T.; Kubota, H.; Makino, H.; Sakai, T.; Oishi, K.; Kushiro, A.; Fujimoto, J.; Watanabe, K.; Watanuki, M.; et al. Ethnic diversity of gut microbiota: Species characterization of Bacteroides fragilis group and genus Bifidobacterium in healthy Belgian adults, and comparison with data from Japanese subjects. J. Biosci. Bioeng. 2013, 116, 265-270. [CrossRef] [PubMed]

39. Wong, C.; Sugahara, H.; Odamaki, T.; Xiao, J. Different physiological properties of human-residential and non-human-residential bifidobacteria in human health. Benef. Microbes 2018, 9, 111-122. [CrossRef] [PubMed]

40. Turroni, F.; Peano, C.; Pass, D.A.; Foroni, E.; Severgnini, M.; Claesson, M.J.; Kerr, C.; Hourihane, J.; Murray, D.; Fuligni, F.; et al. Diversity of Bifidobacteria within the Infant Gut Microbiota. PLoS ONE 2012, 7, e36957. [CrossRef] [PubMed]

41. Odamaki, T.; Bottacini, F.; Kato, K.; Mitsuyama, E.; Yoshida, K.; Horigome, A.; Xiao, J.-Z.; Van Sinderen, D. Genomic diversity and distribution of Bifidobacterium longum subsp. longum across the human lifespan. Sci. Rep. 2018, 8, 85. [CrossRef]

42. Reuter, G. The Lactobacillus and Bifidobacterium microflora of the human intestine: Composition and succession. Curr. Issues Intest. Microbiol. 2001, 2, 43-53.

43. Aagaard, K.; Ma, J.; Antony, K.M.; Ganu, R.; Petrosino, J.; Versalovic, J. The Placenta Harbors a Unique Microbiome. Sci. Transl. Med. 2014, 6, 237ra65. [CrossRef]

44. Collado, M.C.; Rautava, S.; Aakko, J.; Isolauri, E.; Salminen, S. Human gut colonisation may be initiated in utero by distinct microbial communities in the placenta and amniotic fluid. Sci. Rep. 2016, 6, 23129. [CrossRef]

45. De Goffau, M.; Lager, S.; Sovio, U.; Gaccioli, F.; Cook, E.; Peacock, S.J.; Parkhill, J.; Charnock-Jones, D.S.; Smith, G. Human placenta has no microbiome but can contain potential pathogens. Nature 2019, 572, 329-334. [CrossRef]

46. Perez-Muñoz, M.E.; Arrieta, M.-C.; Ramer-Tait, A.E.; Walter, J. A critical assessment of the "sterile womb" and "in utero colonization" hypotheses: Implications for research on the pioneer infant microbiome. Microbiome 2017, 5, 48. [CrossRef]

47. Makino, H. Bifidobacterial strains in the intestines of newborns originate from their mothers. Biosci. Microbiota Food Health 2018, 37, 79-85. [CrossRef] [PubMed]

48. Makino, H.; Kushiro, A.; Ishikawa, E.; Kubota, H.; Gawad, A.; Sakai, T.; Oishi, K.; Martin, R.; Ben-Amor, K.; Knol, J.; et al. Motherto-Infant Transmission of Intestinal Bifidobacterial Strains Has an Impact on the Early Development of Vaginally Delivered Infant's Microbiota. PLoS ONE 2013, 8, e78331. [CrossRef] [PubMed]

49. Milani, C.; Mancabelli, L.; Lugli, G.A.; Duranti, S.; Turroni, F.; Ferrario, C.; Mangifesta, M.; Viappiani, A.; Ferretti, P.; Gorfer, V.; et al. Exploring Vertical Transmission of Bifidobacteria from Mother to Child. Appl. Environ. Microbiol. 2015, 81, 7078-7087. [CrossRef]

50. Kumar, H.; Collado, M.C.; Wopereis, H.; Salminen, S.; Knol, J.; Roeselers, G. The Bifidogenic Effect Revisited-Ecology and Health Perspectives of Bifidobacterial Colonization in Early Life. Microorganisms 2020, 8, 1855. [CrossRef] [PubMed]

51. Butel, M.-J.; Waligora-Dupriet, A.-J.; Wydau-Dematteis, S. The developing gut microbiota and its consequences for health. J. Dev. Orig. Health Dis. 2018, 9, 590-597. [CrossRef] [PubMed]

52. Mikami, K.; Takahashi, H.; Kimura, M.; Isozaki, M.; Izuchi, K.; Shibata, R.; Sudo, N.; Matsumoto, H.; Koga, Y. Influence of Maternal Bifidobacteria on the Establishment of Bifidobacteria Colonizing the Gut in Infants. Pediatr. Res. 2009, 65, 669-674. [CrossRef]

53. Albesharat, R.; Ehrmann, M.A.; Korakli, M.; Yazaji, S.; Vogel, R.F. Phenotypic and genotypic analyses of lactic acid bacteria in local fermented food, breast milk and faeces of mothers and their babies. Syst. Appl. Microbiol. 2011, 34, 148-155. [CrossRef] [PubMed]

54. Matsumiya, Y.; Kato, N.; Watanabe, K.; Kato, H. Molecular epidemiological study of vertical transmission of vaginal Lactobacillus species from mothers to newborn infants in Japanese, by arbitrarily primed polymerase chain reaction. J. Infect. Chemother. 2002, 8, 43-49. [CrossRef]

55. Makino, H.; Kushiro, A.; Ishikawa, E.; Muylaert, D.; Kubota, H.; Sakai, T.; Oishi, K.; Martin, R.; Ben Amor, K.; Oozeer, R.; et al. Transmission of Intestinal Bifidobacterium longum subsp.longumStrains from Mother to Infant, Determined by Multilocus Sequencing Typing and Amplified Fragment Length Polymorphism. Appl. Environ. Microbiol. 2011, 77, 6788-6793. [CrossRef] 
56. Duranti, S.; Lugli, G.A.; Mancabelli, L.; Armanini, F.; Turroni, F.; James, K.; Ferretti, P.; Gorfer, V.; Ferrario, C.; Milani, C.; et al. Maternal inheritance of bifidobacterial communities and bifidophages in infants through vertical transmission. Microbiome 2017, 5, 66. [CrossRef]

57. Asnicar, F.; Manara, S.; Zolfo, M.; Truong, D.T.; Scholz, M.; Armanini, F.; Ferretti, P.; Gorfer, V.; Pedrotti, A.; Tett, A.; et al. Studying Vertical Microbiome Transmission from Mothers to Infants by Strain-Level Metagenomic Profiling. MSystems 2017, 2, e00164-16. [CrossRef]

58. Ferretti, P.; Pasolli, E.; Tett, A.; Asnicar, F.; Gorfer, V.; Fedi, S.; Armanini, F.; Truong, D.T.; Manara, S.; Zolfo, M.; et al. Mother-toInfant Microbial Transmission from Different Body Sites Shapes the Developing Infant Gut Microbiome. Cell Host Microbe 2018, 24, 133-145. [CrossRef] [PubMed]

59. Biagi, E.; Quercia, S.; Aceti, A.; Beghetti, I.; Rampelli, S.; Turroni, S.; Faldella, G.; Candela, M.; Brigidi, P.; Corvaglia, L. The Bacterial Ecosystem of Mother's Milk and Infant's Mouth and Gut. Front. Microbiol. 2017, 8, 1214. [CrossRef] [PubMed]

60. Selma-Royo, M.; Lerma, J.C.; Cortés-Macías, E.; Collado, M.C. Human milk microbiome: From actual knowledge to future perspective. Semin. Perinatol. 2021, 45, 151450. [CrossRef] [PubMed]

61. Cortés-Macías, E.; Selma-Royo, M.; Martínez-Costa, C.; Collado, M. Breastfeeding Practices Influence the Breast Milk Microbiota Depending on Pre-Gestational Maternal BMI and Weight Gain over Pregnancy. Nutrients 2021, 13, 1518. [CrossRef]

62. Cortes-Macías, E.; Selma-Royo, M.; García-Mantrana, I.; Calatayud, M.; González, S.; Martínez-Costa, C.; Collado, M.C. Maternal Diet Shapes the Breast Milk Microbiota Composition and Diversity: Impact of Mode of Delivery and Antibiotic Exposure. J. Nutr. 2020, 151, 330-340. [CrossRef]

63. Bode, L. The functional biology of human milk oligosaccharides. Early Hum. Dev. 2015, 91, 619-622. [CrossRef]

64. Wiciński, M.; Sawicka, E.; Gebalski, J.; Kubiak, K.; Malinowski, B. Human Milk Oligosaccharides: Health Benefits, Potential Applications in Infant Formulas, and Pharmacology. Nutrients 2020, 12, 266. [CrossRef]

65. Sakanaka, M.; Gotoh, A.; Yoshida, K.; Odamaki, T.; Koguchi, H.; Xiao, J.-Z.; Kitaoka, M.; Katayama, T. Varied Pathways of Infant Gut-Associated Bifidobacterium to Assimilate Human Milk Oligosaccharides: Prevalence of the Gene Set and Its Correlation with Bifidobacteria-Rich Microbiota Formation. Nutrients 2019, 12, 71. [CrossRef]

66. Ríos-Covián, D.; Ruas-Madiedo, P.; Margolles, A.; Gueimonde, M.; De Los Reyes-Gavilán, C.G.; Salazar, N. Intestinal Short Chain Fatty Acids and their Link with Diet and Human Health. Front. Microbiol. 2016, 7, 185. [CrossRef]

67. Leblanc, J.G.; Chain, F.; Martín, R.; Humaran, L.G.B.; Courau, S.; Langella, P. Beneficial effects on host energy metabolism of short-chain fatty acids and vitamins produced by commensal and probiotic bacteria. Microb. Cell Factories 2017, 16, 79. [CrossRef] [PubMed]

68. Zabel, B.; Yde, C.C.; Roos, P.; Marcussen, J.; Jensen, H.M.; Salli, K.; Hirvonen, J.; Ouwehand, A.C.; Morovic, W. Novel Genes and Metabolite Trends in Bifidobacterium longum subsp. infantis Bi-26 Metabolism of Human Milk Oligosaccharide 2'-fucosyllactose. Sci. Rep. 2019, 9, 7983. [CrossRef]

69. Alessandri, G.; Ossiprandi, M.C.; Mac Sharry, J.; Van Sinderen, D.; Ventura, M. Bifidobacterial Dialogue With Its Human Host and Consequent Modulation of the Immune System. Front. Immunol. 2019, 10, 2348. [CrossRef] [PubMed]

70. Motherway, M.O.; Houston, A.; O'Callaghan, G.; Reunanen, J.; O’Brien, F.; O’Driscoll, T.; Casey, P.G.; De Vos, W.M.; Van Sinderen, D.; Shanahan, F. A Bifidobacterial pilus-associated protein promotes colonic epithelial proliferation. Mol. Microbiol. 2018, 111, 287-301. [CrossRef]

71. Ewaschuk, J.B.; Diaz, H.; Meddings, L.; Diederichs, B.; Dmytrash, A.; Backer, J.; Langen, M.L.-V.; Madsen, K.L. Secreted bioactive factors fromBifidobacterium infantisenhance epithelial cell barrier function. Am. J. Physiol. Liver Physiol. 2008, 295, G1025-G1034. [CrossRef] [PubMed]

72. He, F.; Ouwehand, A.C.; Isolauri, E.; Hashimoto, H.; Benno, Y.; Salminen, S. Comparison of mucosal adhesion and species identification of bifidobacteria isolated from healthy and allergic infants. FEMS Immunol. Med. Microbiol. 2001, 30, 43-47. [CrossRef]

73. Martinez, F.A.C.; Balciunas, E.M.; Converti, A.; Cotter, P.D.; de Souza Oliveira, R.P. Bacteriocin production by Bifidobacterium spp. A review. Biotechnol. Adv. 2013, 31, 482-488. [CrossRef]

74. Fukuda, S.; Toh, H.; Hase, K.; Oshima, K.; Nakanishi, Y.; Yoshimura, K.; Tobe, T.; Clarke, J.M.; Topping, D.L.; Suzuki, T.; et al. Bifidobacteria can protect from enteropathogenic infection through production of acetate. Nature 2011, 469, 543-547. [CrossRef]

75. Sugahara, H.; Odamaki, T.; Hashikura, N.; Abe, F.; Xiao, J.-Z. Differences in folate production by bifidobacteria of different origins. Biosci. Microbiota Food Health 2015, 34, 87-93. [CrossRef]

76. Huda, M.N.; Lewis, Z.; Kalanetra, K.M.; Rashid, M.; Ahmad, S.M.; Raqib, R.; Qadri, F.; Underwood, M.A.; Mills, D.A.; Stephensen, C.B. Stool Microbiota and Vaccine Responses of Infants. Pediatrics 2014, 134, e362-e372. [CrossRef]

77. Arboleya, S.; Binetti, A.; Salazar, N.; Fernández, N.; Solís, G.; Barranco, A.H.; Margolles, A.; Reyes-Gavilan, C.D.L.; Gueimonde, M. Establishment and development of intestinal microbiota in preterm neonates. FEMS Microbiol. Ecol. 2011, 79, 763-772. [CrossRef]

78. Arboleya, S.; Sánchez, G.S.; Milani, C.; Duranti, S.; Solís, G.; Fernández, N.; Reyes-Gavilan, C.D.L.; Ventura, M.; Margolles, A.; Gueimonde, M. Intestinal Microbiota Development in Preterm Neonates and Effect of Perinatal Antibiotics. J. Pediatr. 2014, 166, 538-544. [CrossRef]

79. Barrett, E.; Kerr, C.; Murphy, K.; O’Sullivan, O.; Ryan, C.A.; Dempsey, E.M.; Murphy, B.P.; O’Toole, P.W.; Cotter, P.; Fitzgerald, G.F.; et al. The individual-specific and diverse nature of the preterm infant microbiota. Arch. Dis. Child. Fetal Neonatal Ed. 2013, 98, F334-F340. [CrossRef] [PubMed] 
80. Korpela, K.; Blakstad, E.W.; Moltu, S.J.; Strømmen, K.; Nakstad, B.; Rønnestad, A.E.; Brække, K.; Iversen, P.O.; Drevon, C.A.; De Vos, W. Intestinal microbiota development and gestational age in preterm neonates. Sci. Rep. 2018, 8, 2453. [CrossRef]

81. Forsgren, M.; Isolauri, E.; Salminen, S.; Rautava, S. Late preterm birth has direct and indirect effects on infant gut microbiota development during the first six months of life. Acta Paediatr. 2017, 106, 1103-1109. [CrossRef]

82. Hill, C.J.; Lynch, D.B.; Murphy, K.; Ulaszewska, M.; Jeffery, I.; O'Shea, C.A.; Watkins, C.; Dempsey, E.M.; Mattivi, F.; Tuohy, K.; et al. Evolution of gut microbiota composition from birth to 24 weeks in the INFANTMET Cohort. Microbiome 2017, 5, 4. [CrossRef]

83. Masi, A.C.; Stewart, C.J. The role of the preterm intestinal microbiome in sepsis and necrotising enterocolitis. Early Hum. Dev. 2019, 138, 104854. [CrossRef]

84. Plummer, E.L.; for the ProPrems Study Group; Bulach, D.M.; Murray, G.L.; Jacobs, S.E.; Tabrizi, S.N.; Garland, S.M. Gut microbiota of preterm infants supplemented with probiotics: Sub-study of the ProPrems trial. BMC Microbiol. 2018, 18, 184. [CrossRef] [PubMed]

85. Stewart, C.J.; Embleton, N.; Marrs, E.C.L.; Smith, D.P.; Nelson, A.; Abdulkadir, B.; Skeath, T.; Petrosino, J.F.; Perry, J.D.; Berrington, J.E.; et al. Temporal bacterial and metabolic development of the preterm gut reveals specific signatures in health and disease. Microbiome 2016, 4, 67. [CrossRef] [PubMed]

86. Stewart, C.J.; Embleton, N.; Marrs, E.C.L.; Smith, D.P.; Fofanova, T.; Nelson, A.; Skeath, T.; Perry, J.D.; Petrosino, J.F.; Berrington, J.E.; et al. Longitudinal development of the gut microbiome and metabolome in preterm neonates with late onset sepsis and healthy controls. Microbiome 2017, 5, 75. [CrossRef]

87. De Jong, J.C.; Ijssennagger, N.; van Mil, S.W. Breast milk nutrients driving intestinal epithelial layer maturation via Wnt and Notch signaling: Implications for necrotizing enterocolitis. Biochim. Biophys. Acta (BBA)-Mol. Basis Dis. 2021, $1867,166229$. [CrossRef] [PubMed]

88. Qazi, S.A.; Stoll, B.J. Neonatal Sepsis. Pediatr. Infect. Dis. J. 2009, 28, S1-S2. [CrossRef] [PubMed]

89. Carl, M.A.; Ndao, I.M.; Springman, A.C.; Manning, S.; Johnson, J.R.; Johnston, B.D.; Burnham, C.-A.D.; Weinstock, E.S.; Weinstock, G.; Wylie, T.N.; et al. Sepsis From the Gut: The Enteric Habitat of Bacteria That Cause Late-Onset Neonatal Bloodstream Infections. Clin. Infect. Dis. 2014, 58, 1211-1218. [CrossRef]

90. Ye, Q.; Yu, J. A Study on Fucosyltransferase 2 Gene Polymorphism and Secretion Status Related to Neonatal Necrotizing Enterocolitis. J. Healthc. Eng. 2021, 2021, 7219850. [CrossRef] [PubMed]

91. Maynard, C.L.; Elson, C.O.; Hatton, R.; Weaver, C.T. Reciprocal interactions of the intestinal microbiota and immune system. Nature 2012, 489, 231-241. [CrossRef] [PubMed]

92. Brennan, A.-M.; Murphy, B.P.; Kiely, M.E. Optimising preterm nutrition: Present and future. Proc. Nutr. Soc. 2016, 75, 154-161. [CrossRef]

93. Younge, N.E.; Newgard, C.B.; Cotten, C.M.; Goldberg, R.N.; Muehlbauer, M.J.; Bain, J.R.; Stevens, R.D.; O'Connell, T.M.; Rawls, J.F.; Seed, P.C.; et al. Disrupted Maturation of the Microbiota and Metabolome among Extremely Preterm Infants with Postnatal Growth Failure. Sci. Rep. 2019, 9, 8167. [CrossRef]

94. Arboleya, S.; Camblor, P.M.; Solís, G.; Suárez, M.; Fernández, N.; de Los Reyes-Gavilan, C.D.L.; Gueimonde, M. Intestinal Microbiota and Weight-Gain in Preterm Neonates. Front. Microbiol. 2017, 8, 183. [CrossRef]

95. Blanton, L.V.; Charbonneau, M.R.; Salih, T.; Barratt, M.J.; Venkatesh, S.; Ilkaveya, O.; Subramanian, S.; Manary, M.J.; Trehan, I.; Jorgensen, J.M.; et al. Gut bacteria that prevent growth impairments transmitted by microbiota from malnourished children. Science 2016, 351, aad3311. [CrossRef]

96. Gehrig, J.L.; Venkatesh, S.; Chang, H.-W.; Hibberd, M.C.; Kung, V.L.; Cheng, J.; Chen, R.Y.; Subramanian, S.; Cowardin, C.A.; Meier, M.; et al. Effects of microbiota-directed foods in gnotobiotic animals and undernourished children. Science 2019, $365,6449$. [CrossRef]

97. Raman, A.S.; Gehrig, J.L.; Venkatesh, S.; Chang, H.-W.; Hibberd, M.C.; Subramanian, S.; Kang, G.; Bessong, P.O.; Lima, A.A.; Kosek, M.N.; et al. A sparse covarying unit that describes healthy and impaired human gut microbiota development. Science 2019, 365, 6449. [CrossRef]

98. Penders, J.; Thijs, C.; Vink, C.; Stelma, F.F.; Snijders, B.; Kummeling, I.; Van den Brandt, P.A.; Stobberingh, E.E. Factors Influencing the Composition of the Intestinal Microbiota in Early Infancy. Pediatrics 2006, 118, 511-521. [CrossRef] [PubMed]

99. Dominguez-Bello, M.G.; Costello, E.K.; Contreras, M.; Magris, M.; Hidalgo, G.; Fierer, N.; Knight, R. Delivery mode shapes the acquisition and structure of the initial microbiota across multiple body habitats in newborns. Proc. Natl. Acad. Sci. USA 2010, 107, 11971-11975. [CrossRef] [PubMed]

100. Rutayisire, E.; Huang, K.; Liu, Y.; Tao, F. The mode of delivery affects the diversity and colonization pattern of the gut microbiota during the first year of infants' life: A systematic review. BMC Gastroenterol. 2016, 16, 86. [CrossRef] [PubMed]

101. Werlang, I.C.R.; Mueller, N.T.; Pizoni, A.; Wisintainer, H.; Matte, U.; Costa, S.H.D.A.M.; Ramos, J.G.L.; Goldani, M.Z.; DominguezBello, M.G.; Goldani, H.A.S. Associations of birth mode with cord blood cytokines, white blood cells, and newborn intestinal bifidobacteria. PLoS ONE 2018, 13, e0205962. [CrossRef]

102. Morais, L.H.; Golubeva, A.V.; Moloney, G.M.; Moya-Pérez, A.; Ventura-Silva, A.P.; Arboleya, S.; Bastiaanssen, T.F.; O’Sullivan, O.; Rea, K.; Borre, Y.; et al. Enduring Behavioral Effects Induced by Birth by Caesarean Section in the Mouse. Curr. Biol. 2020, 30, 3761-3774.e6. [CrossRef] 
103. Reyman, M.; Van Houten, M.A.; Van Baarle, D.; Bosch, A.A.T.M.; Man, W.H.; Chu, M.L.J.N.; Arp, K.; Watson, R.L.; Sanders, E.A.M.; Fuentes, S.; et al. Author Correction: Impact of delivery mode-associated gut microbiota dynamics on health in the first year of life. Nat. Commun. 2019, 10, 5352. [CrossRef]

104. Nogacka, A.; Salazar, N.; Suárez, M.; Milani, C.; Arboleya, S.; Solís, G.; Fernández, N.; Alaez, L.; Hernández-Barranco, A.M.; Reyes-Gavilan, C.D.L.; et al. Impact of intrapartum antimicrobial prophylaxis upon the intestinal microbiota and the prevalence of antibiotic resistance genes in vaginally delivered full-term neonates. Microbiome 2017, 5, 93. [CrossRef]

105. Imoto, N.; Morita, H.; Amanuma, F.; Maruyama, H.; Watanabe, S.; Hashiguchi, N. Maternal antimicrobial use at delivery has a stronger impact than mode of delivery on bifidobacterial colonization in infants: A pilot study. J. Perinatol. 2018, 38, 1174-1181. [CrossRef]

106. Saturio, S.; Suárez, M.; Mancabelli, L.; Fernández, N.; Mantecón, L.; Reyes-Gavilán, C.G.D.L.; Ventura, M.; Gueimonde, M.; Arboleya, S.; Solís, G. Effect of Intrapartum Antibiotics Prophylaxis on the Bifidobacterial Establishment within the Neonatal Gut. Microorganisms 2021, 9, 1867. [CrossRef]

107. Fouhy, F.; Guinane, C.; Hussey, S.; Wall, R.; Ryan, C.A.; Dempsey, E.M.; Murphy, B.; Ross, R.; Fitzgerald, G.F.; Stanton, C.; et al. High-Throughput Sequencing Reveals the Incomplete, Short-Term Recovery of Infant Gut Microbiota following Parenteral Antibiotic Treatment with Ampicillin and Gentamicin. Antimicrob. Agents Chemother. 2012, 56, 5811-5820. [CrossRef] [PubMed]

108. Uzan-Yulzari, A.; Turta, O.; Belogolovski, A.; Ziv, O.; Kunz, C.; Perschbacher, S.; Neuman, H.; Pasolli, E.; Oz, A.; Ben-Amram, H.; et al. Neonatal antibiotic exposure impairs child growth during the first six years of life by perturbing intestinal microbial colonization. Nat. Commun. 2021, 12, 443. [CrossRef] [PubMed]

109. Turta, O.; Rautava, S. Antibiotics, obesity and the link to microbes-What are we doing to our children? BMC Med. 2016, 14, 57. [CrossRef] [PubMed]

110. Afshin, A.; Forouzanfar, M.H.; Reitsma, M.B.; Sur, P.; Estep, K.; Lee, A.; Marczak, L.; Mokdad, A.H.; Moradi-Lakeh, M.; Naghavi, M.; et al. Health Effects of Overweight and Obesity in 195 Countries over 25 Years. N. Engl. J. Med. 2017, 377, 13-27. [CrossRef]

111. Soderborg, T.K.; Clark, S.; Mulligan, C.E.; Janssen, R.C.; Babcock, L.; Ir, D.; Young, B.; Krebs, N.; Lemas, D.J.; Johnson, L.K.; et al. The gut microbiota in infants of obese mothers increases inflammation and susceptibility to NAFLD. Nat. Commun. 2018, 9, 4462, Correction in 2019, 10, 2965. [CrossRef]

112. Collado, M.C.; Cernada, M.; Bäuerl, C.; Vento, M.; Pérez-Martínez, G. Microbial ecology and host-microbiota interactions during early life stages. Gut Microbes 2012, 3, 352-365. [CrossRef]

113. Dreisbach, C.; Prescott, S.; Alhusen, J. Influence of Maternal Prepregnancy Obesity and Excessive Gestational Weight Gain on Maternal and Child Gastrointestinal Microbiome Composition: A Systematic Review. Biol. Res. Nurs. 2019, 22, 114-125. [CrossRef]

114. Kim, H.; Sitarik, A.R.; Woodcroft, K.; Johnson, C.C.; Zoratti, E. Birth Mode, Breastfeeding, Pet Exposure, and Antibiotic Use: Associations With the Gut Microbiome and Sensitization in Children. Curr. Allergy Asthma Rep. 2019, 19, 22. [CrossRef]

115. Tun, H.; Bridgman, S.L.; Chari, R.; Field, C.; Guttman, D.S.; Becker, A.B.; Mandhane, P.J.; Turvey, S.; Subbarao, P.; Sears, M.R.; et al. Roles of Birth Mode and Infant Gut Microbiota in Intergenerational Transmission of Overweight and Obesity From Mother to Offspring. JAMA Pediatr. 2018, 172, 368-377. [CrossRef]

116. Sutharsan, R.; Mannan, M.; Doi, A.S.; Al Mamun, A. Caesarean delivery and the risk of offspring overweight and obesity over the life course: A systematic review and bias-adjusted meta-analysis. Clin. Obes. 2015, 5, 293-301. [CrossRef]

117. Vu, K.; Lou, W.; Tun, H.M.; Konya, T.B.; Morales-Lizcano, N.; Chari, R.S.; Field, C.J.; Guttman, D.S.; Mandal, R.; Wishart, D.S.; et al. From Birth to Overweight and Atopic Disease: Multiple and Common Pathways of the Infant Gut Microbiome. Gastroenterology 2021, 160, 128-144.e10. [CrossRef] [PubMed]

118. Korpela, K.; Zijlmans, M.A.C.; Kuitunen, M.; Kukkonen, K.; Savilahti, E.; Salonen, A.; De Weerth, C.; De Vos, W.M. Childhood $\mathrm{BMI}$ in relation to microbiota in infancy and lifetime antibiotic use. Microbiome 2017, 5, 26. [CrossRef] [PubMed]

119. Murri, M.; Leiva, I.; Gomez-Zumaquero, J.M.; Tinahones, F.J.; Cardona, F.; Soriguer, F.; Queipo-Ortuño, M.I. Gut microbiota in children with type 1 diabetes differs from that in healthy children: A case-control study. BMC Med. 2013, 11, 46. [CrossRef]

120. Isolauri, E. Development of healthy gut microbiota early in life. J. Paediatr. Child Health 2012, 48, 1-6. [CrossRef] [PubMed]

121. Asher, M.I.; Montefort, S.; Björkstén, B.; Lai, C.K.; Strachan, D.P.; Weiland, S.K.; Williams, H. Worldwide time trends in the prevalence of symptoms of asthma, allergic rhinoconjunctivitis, and eczema in childhood: ISAAC Phases One and Three repeat multicountry cross-sectional surveys. Lancet 2006, 368, 733-743. [CrossRef]

122. Wold, A.E. The hygiene hypotheslis revised: Is the rising frequency of allergy due to changes in the intestinal flora? Allergy 1998, 53, 20-25. [CrossRef]

123. Alfven, T.; Braun-Fahrlander, C.; Brunekreef, B.; von Mutius, E.; Riedler, J.; Scheynius, A.; van Hage, M.; Wickman, M.; Benz, M.R.; Budde, J.; et al. Allergic diseases and atopic sensitization in children related to farming and anthroposophic lifestyle-The PARSIFAL study. Allergy 2006, 61, 414-421. [CrossRef]

124. Fieten, K.B.; Totté, J.E.; Levin, E.; Reyman, M.; Meijer, Y.; Knulst, A.; Schuren, F.; Pasmans, S.G. Fecal Microbiome and Food Allergy in Pediatric Atopic Dermatitis: A Cross-Sectional Pilot Study. Int. Arch. Allergy Immunol. 2018, 175, 77-84. [CrossRef]

125. Ruohtula, T.; de Goffau, M.; Nieminen, J.K.; Honkanen, J.; Siljander, H.; Hämäläinen, A.-M.; Peet, A.; Tillmann, V.; Ilonen, J.; Niemelä, O.; et al. Maturation of Gut Microbiota and Circulating Regulatory T Cells and Development of IgE Sensitization in Early Life. Front. Immunol. 2019, 10, 2494. [CrossRef] 
126. Low, J.S.Y.; Soh, E.S.; Lee, Y.K.; Kwek, K.Y.C.; Holbrook, J.D.; Van Der Beek, E.M.; Shek, L.; Goh, A.E.N.; Teoh, O.H.; Godfrey, K.M.; et al. Ratio of Klebsiella/Bifidobacterium in early life correlates with later development of paediatric allergy. Benef. Microbes 2017, 8, 681-695. [CrossRef]

127. Zhang, Y.; Jin, S.; Wang, J.; Zhang, L.; Mu, Y.; Huang, K.; Zhao, B.; Zhang, K.; Cui, Y.; Li, S. Variations in early gut microbiome are associated with childhood eczema. FEMS Microbiol. Lett. 2019, 366, fnz020. [CrossRef]

128. Sjödin, K.S.; Hammarström, M.-L.; Rydén, P.; Sjödin, A.; Hernell, O.; Engstrand, L.; West, C.E. Temporal and long-term gut microbiota variation in allergic disease: A prospective study from infancy to school age. Allergy 2018, 74, 176-185. [CrossRef]

129. Melli, L.C.F.L.; Carmo-Rodrigues, M.S.D.; Araújo-Filho, H.B.; Mello, C.; Tahan, S.; Pignatari, A.C.C.; Solé, D.; de Morais, M.B. Gut microbiota of children with atopic dermatitis: Controlled study in the metropolitan region of São Paulo, Brazil. Allergol. Immunopathol. 2020, 48, 107-115. [CrossRef]

130. Guo, L.; Bai, H.; Dong, Y.; Huang, D.X.; Zhang, X.; Gong, S.; Zhao, X.; Fei, P. Comparative Analysis of Fecal Microbiota in 5-8-Year-old Children with and without Cow Milk Protein Allergy. Iran. J. Pediatr. 2016, 26, e6397. [CrossRef]

131. Melli, L.; Carmo-Rodrigues, M.D.; Araújo-Filho, H.; Solé, D.; de Morais, M.B. Intestinal microbiota and allergic diseases: A systematic review. Allergol. Immunopathol. 2016, 44, 177-188. [CrossRef]

132. Mah, K.; Björkstén, B.; Lee, B.; Van Bever, H.; Shek, L.; Tan, T.; Lee, Y.; Chua, K. Distinct Pattern of Commensal Gut Microbiota in Toddlers with Eczema. Int. Arch. Allergy Immunol. 2006, 140, 157-163. [CrossRef] [PubMed]

133. Watanabe, S.; Narisawa, Y.; Arase, S.; Okamatsu, H.; Ikenaga, T.; Tajiri, Y.; Kumemura, M. Differences in fecal microflora between patients with atopic dermatitis and healthy control subjects. J. Allergy Clin. Immunol. 2003, 111, 587-591. [CrossRef] [PubMed]

134. Lu, L.; Barbi, J.; Pan, F. The regulation of immune tolerance by FOXP. Nat. Rev. Immunol. 2017, 17, 703-717. [CrossRef]

135. Zuo, L.; Yuan, K.-T.; Yu, L.; Meng, Q.-H.; Chung, P.C.-K.; Yang, D.-H. Bifidobacterium infantisattenuates colitis by regulating T cell subset responses. World J. Gastroenterol. 2014, 20, 18316-18329. [CrossRef]

136. Ashraf, R.; Vasiljevic, T.; Day, S.; Smith, S.; Donkor, O. Lactic acid bacteria and probiotic organisms induce different cytokine profile and regulatory T cells mechanisms. J. Funct. Foods 2014, 6, 395-409. [CrossRef]

137. Verma, R.; Lee, C.; Jeun, E.-J.; Yi, J.; Kim, K.S.; Ghosh, A.; Byun, S.; Lee, C.-G.; Kang, H.-J.; Kim, G.-C.; et al. Cell surface polysaccharides of Bifidobacterium bifidum induce the generation of Foxp3 + regulatory T cells. Sci. Immunol. 2018, 3, eaat6975. [CrossRef] [PubMed]

138. Melnik, B.C.; John, S.M.; Carrera-Bastos, P.; Schmitz, G. Milk: A postnatal imprinting system stabilizing FoxP3 expression and regulatory $\mathrm{T}$ cell differentiation. Clin. Transl. Allergy 2016, 6, 18. [CrossRef] [PubMed]

139. Sayal, K.; Heron, J.; Maughan, B.; Rowe, R.; Ramchandani, P. Infant temperament and childhood psychiatric disorder: Longitudinal study. Child Care Health Dev. 2013, 40, 292-297. [CrossRef]

140. Sampson, T.R.; Mazmanian, S.K. Control of Brain Development, Function, and Behavior by the Microbiome. Cell Host Microbe 2015, 17, 565-576. [CrossRef] [PubMed]

141. Aatsinki, A.-K.; Lahti, L.; Uusitupa, H.-M.; Munukka, E.; Keskitalo, A.; Nolvi, S.; O’Mahony, S.; Pietilä, S.; Elo, L.L.; Eerola, E.; et al. Gut microbiota composition is associated with temperament traits in infants. Brain Behav. Immun. 2019, 80, 849-858. [CrossRef] [PubMed]

142. Wang, Y.; Chen, X.; Yu, Y.; Liu, Y.; Zhang, Q.; Bai, J. Association between Gut Microbiota and Infant's Temperament in the First Year of Life in a Chinese Birth Cohort. Microorganisms 2020, 8, 753. [CrossRef]

143. Kelsey, C.M.; Prescott, S.; McCulloch, J.A.; Trinchieri, G.; Valladares, T.L.; Dreisbach, C.; Alhusen, J.; Grossmann, T. Gut microbiota composition is associated with newborn functional brain connectivity and behavioral temperament. Brain Behav. Immun. 2020, 91, 472-486. [CrossRef] [PubMed]

144. Coretti, L.; Paparo, L.; Riccio, M.P.; Amato, F.; Cuomo, M.; Natale, A.; Borrelli, L.; Corrado, G.; De Caro, C.; Comegna, M.; et al. Gut Microbiota Features in Young Children with Autism Spectrum Disorders. Front. Microbiol. 2018, 9, 3146. [CrossRef]

145. Bojović, K.; Ignjatović, Đ.; Bajic, S.S.; Milutinović, D.V.; Tomić, M.; Golić, N.; Tolinački, M. Gut Microbiota Dysbiosis Associated With Altered Production of Short Chain Fatty Acids in Children With Neurodevelopmental Disorders. Front. Cell. Infect. Microbiol. 2020, 10, 223. [CrossRef]

146. Flannery, J.E.; Stagaman, K.; Burns, A.R.; Hickey, R.J.; Roos, L.E.; Giuliano, R.J.; Fisher, P.A.; Sharpton, T.J. Gut Feelings Begin in Childhood: The Gut Metagenome Correlates with Early Environment, Caregiving, and Behavior. MBio 2020, 11, e02780-19. [CrossRef]

147. Golubeva, A.V.; Joyce, A.S.; Moloney, G.; Burokas, A.; Sherwin, E.; Arboleya, S.; Flynn, I.; Khochanskiy, D.; Moya-Pérez, A.; Peterson, V.; et al. Microbiota-related Changes in Bile Acid \& Tryptophan Metabolism are Associated with Gastrointestinal Dysfunction in a Mouse Model of Autism. EBioMedicine 2017, 24, 166-178. [CrossRef] [PubMed]

148. Luk, B.; Veeraragavan, S.; Engevik, M.; Balderas, M.; Major, A.; Runge, J.; Luna, R.A.; Versalovic, J. Postnatal colonization with human "infant-type" Bifidobacterium species alters behavior of adult gnotobiotic mice. PLoS ONE 2018, 13, e0196510. [CrossRef]

149. Ehrlich, A.M.; Henrick, B.; Pacheco, A.; Taft, D.; Xu, G.; Huda, N.; Lozada-Contreras, M.; Goodson, M.; Slupsky, C.; Mills, D.; et al. Bifidobacterium grown on human milk oligosaccharides produce tryptophan metabolite Indole-3-lactic acid that significantly decreases inflammation in intestinal cells In Vitro. FASEB J. 2018, 32, lb359. [CrossRef]

150. Sakurai, T.; Odamaki, T.; Xiao, J.-Z. Production of Indole-3-Lactic Acid by Bifidobacterium Strains Isolated from Human Infants. Microorganisms 2019, 7, 340. [CrossRef] [PubMed] 
151. Wong, C.B.; Tanaka, A.; Kuhara, T.; Xiao, J.-Z. Potential Effects of Indole-3-Lactic Acid, a Metabolite of Human Bifidobacteria, on NGF-Induced Neurite Outgrowth in PC12 Cells. Microorganisms 2020, 8, 398. [CrossRef] [PubMed]

152. Ehrlich, A.M.; Pacheco, A.R.; Henrick, B.M.; Taft, D.; Xu, G.; Huda, M.N.; Mishchuk, D.; Goodson, M.L.; Slupsky, C.; Barile, D.; et al. Indole-3-lactic acid associated with Bifidobacterium-dominated microbiota significantly decreases inflammation in intestinal epithelial cells. BMC Microbiol. 2020, 20, 357. [CrossRef]

153. Wang, B.; Brand-Miller, J.; McNeil, Y.; McVeagh, P. Sialic Acid Concentration of Brain Gangliosides: Variation among Eight Mammalian Species. Comp. Biochem. Physiol. Part A Mol. Integr. Physiol. 1998, 119, 435-439. [CrossRef]

154. Wang, B.; McVeagh, P.; Petocz, P.; Brand-Miller, J. Brain ganglioside and glycoprotein sialic acid in breastfed compared with formula-fed infants. Am. J. Clin. Nutr. 2003, 78, 1024-1029. [CrossRef]

155. Tannock, G.W.; Lee, P.S.; Wong, K.H.; Lawley, B. Why Don't All Infants Have Bifidobacteria in Their Stool? Front. Microbiol. 2016, 7, 834. [CrossRef]

156. Hill, C.; Guarner, F.; Reid, G.; Gibson, G.R.; Merenstein, D.J.; Pot, B.; Morelli, L.; Canani, R.B.; Flint, H.J.; Salminen, S.; et al. Expert Consensus Document: The International Scientific Association for Probiotics and Prebiotics consensus statement on the scope and appropriate use of the term probiotic. Nat. Rev. Gastroenterol. Hepatol. 2014, 11, 506-514. [CrossRef]

157. Arboleya, S.; Salazar, N.; Solís, G.; Fernández, N.; Gueimonde, M.; Reyes-Gavilán, C.G.D.L. In Vitro evaluation of the impact of human background microbiota on the response to Bifidobacterium strains and fructo-oligosaccharides. Br. J. Nutr. 2013, 110, 2030-2036. [CrossRef]

158. El Aidy, S.; Hooiveld, G.; Tremaroli, V.; Bäckhed, F.; Kleerebezem, M. The gut microbiota and mucosal homeostasis. Gut Microbes 2013, 4, 118-124. [CrossRef]

159. Kiu, R.; Treveil, A.; Harnisch, L.C.; Caim, S.; Leclaire, C.; van Sinderen, D.; Korcsmaros, T.; Hall, L.J. Bifidobacterium breve UCC2003 Induces a Distinct Global Transcriptomic Program in Neonatal Murine Intestinal Epithelial Cells. IScience 2020, 23, 101336. [CrossRef]

160. Rigo-Adrover, M.D.M.; Franch, A.; Castell, M.; Pérez-Cano, F.J. Preclinical Immunomodulation by the Probiotic Bifidobacterium breve M-16V in Early Life. PLoS ONE 2016, 11, e0166082. [CrossRef] [PubMed]

161. Ohtsuka, Y.; Ikegami, T.; Izumi, H.; Namura, M.; Ikeda, T.; Ikuse, T.; Baba, Y.; Kudo, T.; Suzuki, R.; Shimizu, T. Effects of Bifidobacterium breve on inflammatory gene expression in neonatal and weaning rat intestine. Pediatr. Res. 2011, 71, 46-53. [CrossRef] [PubMed]

162. Ehara, T.; Izumi, H.; Tsuda, M.; Nakazato, Y.; Iwamoto, H.; Namba, K.; Takeda, Y. Combinational effects of prebiotic oligosaccharides on bifidobacterial growth and host gene expression in a simplified mixed culture model and neonatal mice. Br. J. Nutr. 2016, 116, 270-278. [CrossRef] [PubMed]

163. Izumi, H.; Ehara, T.; Sugahara, H.; Matsubara, T.; Mitsuyama, E.; Nakazato, Y.; Tsuda, M.; Shimizu, T.; Odamaki, T.; Xiao, J.-Z.; et al. The Combination of Bifidobacterium breve and Three Prebiotic Oligosaccharides Modifies Gut Immune and Endocrine Functions in Neonatal Mice. J. Nutr. 2019, 149, 344-353. [CrossRef]

164. Lyons, A.; O’Mahony, D.; O’Brien, F.; Mac Sharry, J.; Sheil, B.; Ceddia, M.; Russell, W.M.; Forsythe, P.; Bienenstock, J.; Kiely, B.; et al. Bacterial strain-specific induction of Foxp3+T regulatory cells is protective in murine allergy models. Clin. Exp. Allergy 2010, 40, 811-819. [CrossRef]

165. Sudo, N.; Sawamura, S.A.; Tanaka, K.; Aiba, Y.; Kubo, C.; Koga, Y. The requirement of intestinal bacterial flora for the development of an ige production system fully susceptible to oral tolerance induction. J. Immunol. 1997, 159, $1739-1745$.

166. Tanaka, K.; Ishikawa, H. Role of intestinal bacterial flora in oral tolerance induction. Histol. Histopathol. 2004, 19, 907-914. [CrossRef]

167. Cheng, R.; Yao, J.; Wan, Q.; Guo, J.; Pu, F.; Shi, L.; Hu, W.; Yang, Y.; Li, L.; Li, M.; et al. Oral administration of Bifidobacterium bifidum TMC3115 to neonatal mice may alleviate IgE-mediated allergic risk in adulthood. Benef. Microbes 2018, 9, 815-828. [CrossRef] [PubMed]

168. Feleszko, W.; Jaworska, J.; Rha, R.-D.; Steinhausen, S.; Avagyan, A.; Jaudszus, A.; Ahrens, B.; Groneberg, D.A.; Wahn, U.; Hamelmann, E. Probiotic-induced suppression of allergic sensitization and airway inflammation is associated with an increase of T regulatory-dependent mechanisms in a murine model of asthma. Clin. Exp. Allergy 2006, 37, 498-505. [CrossRef] [PubMed]

169. Terada-Ikeda, C.; Kitabatake, M.; Hiraku, A.; Kato, K.; Yasui, S.; Imakita, N.; Ouji-Sageshima, N.; Iwabuchi, N.; Hamada, K.; Ito, T. Maternal supplementation with Bifidobacterium breve M-16V prevents their offspring from allergic airway inflammation accelerated by the prenatal exposure to an air pollutant aerosol. PLoS ONE 2020, 15, e0238923. [CrossRef]

170. Schwarzer, M.; Srutkova, D.; Schabussova, I.; Hudcovic, T.; Akgün, J.; Wiedermann, U.; Kozakova, H. Neonatal colonization of germ-free mice with Bifidobacterium longum prevents allergic sensitization to major birch pollen allergen Bet v1. Vaccine 2013, 31, 5405-5412. [CrossRef]

171. Kostadinova, A.I.; Meulenbroek, L.A.P.M.; Van Esch, B.C.A.M.; Hofman, G.A.; Garssen, J.; Willemsen, L.E.M.; Knippels, L.M.J. A Specific Mixture of Fructo-Oligosaccharides and Bifidobacterium breve M-16V Facilitates Partial Non-Responsiveness to Whey Protein in Mice Orally exposed to $\beta$-Lactoglobulin-Derived Peptides. Front. Immunol. 2017, 7, 673. [CrossRef]

172. Schouten, B.; Van Esch, B.C.A.M.; Hofman, G.A.; Van Doorn, S.A.C.M.; Knol, J.; Nauta, A.J.; Garssen, J.; Willemsen, L.E.M.; Knippels, L.M.J. Cow Milk Allergy Symptoms Are Reduced in Mice Fed Dietary Synbiotics during Oral Sensitization with Whey. J. Nutr. 2009, 139, 1398-1403. [CrossRef] 
173. Sasajima, N.; Ogasawara, T.; Takemura, N.; Fujiwara, R.; Watanabe, J.; Sonoyama, K. Role of intestinal bifidobacterium pseudolongum in dietary fructo-oligosaccharide inhibition of 2,4-dinitrofluorobenzene-induced contact hypersensitivity in mice. Br. J. Nutr. 2010, 103, 539-548. [CrossRef]

174. Cheng, R.; Guo, J.; Pu, F.; Wan, C.; Shi, L.; Li, H.; Yang, Y.; Huang, C.; Li, M.; He, F. Loading ceftriaxone, vancomycin, and Bifidobacteria bifidum TMC3115 to neonatal mice could differently and consequently affect intestinal microbiota and immunity in adulthood. Sci. Rep. 2019, 9, 3254. [CrossRef]

175. Luck, B.; Engevik, M.A.; Ganesh, B.; Lackey, E.P.; Lin, T.; Balderas, M.; Major, A.; Runge, J.; Luna, R.A.; Sillitoe, R.V.; et al. Bifidobacteria shape host neural circuits during postnatal development by promoting synapse formation and microglial function. Sci. Rep. 2020, 10, 7737. [CrossRef]

176. Moya-Pérez, A.; Perez-Villalba, A.; Benitez-Paez, A.; Campillo, I.; Sanz, Y. Bifidobacterium CECT 7765 modulates early stressinduced immune, neuroendocrine and behavioral alterations in mice. Brain Behav. Immun. 2017, 65, 43-56. [CrossRef]

177. Sudo, N.; Chida, Y.; Aiba, Y.; Sonoda, J.; Oyama, N.; Yu, X.-N.; Kubo, C.; Koga, Y. Postnatal microbial colonization programs the hypothalamic-pituitary-adrenal system for stress response in mice. J. Physiol. 2004, 558, 263-275. [CrossRef] [PubMed]

178. Caplan, M.S.; Miller-Catchpole, R.; Kaup§, S.; Russell, T.; Lickerman, M.; Amer, M.; Xiao, Y.; Thomson, R. Bifidobacterial supplementation reduces the incidence of necrotizing enterocolitis in a neonatal rat model. Gastroenterology 1999, 117, 577-583. [CrossRef]

179. Bergmann, K.R.; Liu, S.X.; Tian, R.; Kushnir, A.; Turner, J.R.; Li, H.-L.; Chou, P.M.; Weber, C.; De Plaen, I.G. Bifidobacteria Stabilize Claudins at Tight Junctions and Prevent Intestinal Barrier Dysfunction in Mouse Necrotizing Enterocolitis. Am. J. Pathol. 2013, 182, 1595-1606. [CrossRef] [PubMed]

180. Zhou, W.; Lv, H.; Li, M.; Su, H.; Huang, L.; Li, J.; Yuan, W. Protective effects of bifidobacteria on intestines in newborn rats with necrotizing enterocolitis and its regulation on TLR2 and TLR. Genet. Mol. Res. 2015, 14, 11505-11514. [CrossRef]

181. Wu, W.; Wang, Y.; Zou, J.; Long, F.; Yan, H.; Zeng, L.; Chen, Y. Bifidobacterium adolescentis protects against necrotizing enterocolitis and upregulates TOLLIP and SIGIRR in premature neonatal rats. BMC Pediatr. 2017, 17, 1. [CrossRef]

182. Khailova, L.; Dvorak, K.; Arganbright, K.M.; Halpern, M.D.; Kinouchi, T.; Yajima, M.; Dvorak, B. Bifidobacterium bifidum improves intestinal integrity in a rat model of necrotizing enterocolitis. Am. J. Physiol. Liver Physiol. 2009, 297, G940-G949. [CrossRef]

183. Satoh, T.; Izumi, H.; Iwabuchi, N.; Odamaki, T.; Namba, K.; Abe, F.; Xiao, J. Bifidobacterium breve prevents necrotising enterocolitis by suppressing inflammatory responses in a preterm rat model. Benef. Microbes 2016, 7, 75-82. [CrossRef]

184. Underwood, M.A.; Arriola, J.; Gerber, C.W.; Kaveti, A.; Kalanetra, K.M.; Kananurak, A.; Bevins, C.L.; Mills, D.A.; Dvorak, B Bifidobacterium longum subsp. infantis in experimental necrotizing enterocolitis: Alterations in inflammation, innate immune response, and the microbiota. Pediatr. Res. 2014, 76, 326-333. [CrossRef]

185. Underwood, M.A.; Kananurak, A.; Coursodon, C.F.; Adkins-Reick, C.K.; Chu, H.; Bennett, S.H.; Wehkamp, J.; Castillo, P.A.; Leonard, B.; Tancredi, D.; et al. Bifidobacterium bifidum in a rat model of necrotizing enterocolitis: Antimicrobial peptide and protein responses. Pediatr. Res. 2012, 71, 546-551. [CrossRef]

186. Wu, S.-F.; Chiu, H.-Y.; Chen, A.-C.; Lin, H.-Y.; Lin, H.-C.; Caplan, M. Efficacy of Different Probiotic Combinations on Death and Necrotizing Enterocolitis in a Premature Rat Model. J. Pediatr. Gastroenterol. Nutr. 2013, 57, 23-28. [CrossRef]

187. Geerlings, S.Y.; Kostopoulos, I.; De Vos, W.M.; Belzer, C. Akkermansia muciniphila in the Human Gastrointestinal Tract: When, Where, and How? Microorganisms 2018, 6, 75. [CrossRef] [PubMed]

188. Yasui, H.; Kiyoshima, J.; Ushijima, H. Passive Protection against Rotavirus-Induced Diarrhea of Mouse Pups Born to and Nursed by Dams Fed Bifidobacterium breve YIT. J. Infect. Dis. 1995, 172, 403-409. [CrossRef] [PubMed]

189. Qiao, H.; Duffy, L.C.; Griffiths, E.; Dryja, D.; Leavens, A.; Rossman, J.; Rich, G.; Riepenhoff-Talty, M.; Locniskar, M. Immune Responses in Rhesus Rotavirus-Challenged Balb/c Mice Treated with Bifidobacteria and Prebiotic Supplements. Pediatr. Res. 2002, 51, 750-755. [CrossRef] [PubMed]

190. Kang, J.Y.; Lee, D.K.; Ha, N.J.; Shin, H.S. Antiviral effects of Lactobacillus ruminis SPM0211 and Bifidobacterium longum SPM1205 and SPM1206 on rotavirus-infected Caco-2 cells and a neonatal mouse model. J. Microbiol. 2015, 53, 796-803. [CrossRef]

191. Izumi, H.; Minegishi, M.; Sato, Y.; Shimizu, T.; Sekine, K.; Takase, M. Bifidobacterium breve alters immune function and ameliorates DSS-induced inflammation in weanling rats. Pediatr. Res. 2015, 78, 407-416. [CrossRef]

192. Wagner, R.D.; Pierson, C.; Warner, T.; Dohnalek, M.; Farmer, J.; Roberts, L.; Hilty, M.; Balish, E. Biotherapeutic effects of probiotic bacteria on candidiasis in immunodeficient mice. Infect. Immun. 1997, 65, 4165-4172. [CrossRef]

193. Weng, M.; Ganguli, K.; Zhu, W.; Shi, H.N.; Walker, W.A. Conditioned medium from Bifidobacteria infantis protects against Cronobacter sakazakii-induced intestinal inflammation in newborn mice. Am. J. Physiol. Liver Physiol. 2014, 306, G779-G787. [CrossRef]

194. Wong, C.B.; Iwabuchi, N.; Xiao, J.-Z. Exploring the Science behind Bifidobacterium breve M-16V in Infant Health. Nutrients 2019, 11, 1724. [CrossRef]

195. Desbonnet, L.; Clarke, G.; Traplin, A.; O’Sullivan, O.; Crispie, F.; Moloney, R.D.; Cotter, P.; Dinan, T.; Cryan, J. Gut microbiota depletion from early adolescence in mice: Implications for brain and behaviour. Brain Behav. Immun. 2015, 48, 165-173. [CrossRef]

196. Weizman, Z.; Alsheikh, A. Safety and tolerance of a probiotic formula in early infancy comparing two probiotic agents: A pilot study. J. Am. Coll. Nutr. 2006, 25, 415-419. [CrossRef] 
197. Smilowitz, J.T.; Moya, J.; Breck, M.A.; Cook, C.; Fineberg, A.; Angkustsiri, K.; Underwood, M.A. Safety and tolerability of Bifidobacterium longum subspecies infantis EVC001 supplementation in healthy term breastfed infants: A phase I clinical trial. BMC Pediatr. 2017, 17, 133. [CrossRef]

198. Weizman, Z.; Asli, G.; Alsheikh, A. Effect of a Probiotic Infant Formula on Infections in Child Care Centers: Comparison of Two Probiotic Agents. Pediatrics 2005, 115, 5-9. [CrossRef] [PubMed]

199. Grandy, G.; Medina, M.; Soria, R.; Terán, C.G.; Araya, M. Probiotics in the treatment of acute rotavirus diarrhoea. A randomized, double-blind, controlled trial using two different probiotic preparations in Bolivian children. BMC Infect. Dis. 2010, 10, 253. [CrossRef]

200. Vandenplas, Y.; de Hert, S.G. PROBIOTICAL-study group Randomised clinical trial: The synbiotic food supplement Probiotical vs. placebo for acute gastroenteritis in children. Aliment. Pharmacol. Ther. 2011, 34, 862-867. [CrossRef]

201. Escribano, J.; Ferré, N.; Gispert-Llaurado, M.; Luque, V.; Rubio-Torrents, C.; Zaragoza-Jordana, M.; Polanco, I.; Codoñer, F.M.; Chenoll, E.; Morera, M.; et al. Bifidobacterium longum subsp infantis CECT7210-supplemented formula reduces diarrhea in healthy infants: A randomized controlled trial. Pediatr. Res. 2018, 83, 1120-1128. [CrossRef] [PubMed]

202. Chouraqui, J.-P.; Van Egroo, L.-D.; Fichot, M.-C. Acidified Milk Formula Supplemented with Bifidobacterium lactis: Impact on Infant Diarrhea in Residential Care Settings. J. Pediatr. Gastroenterol. Nutr. 2004, 38, 288-292. [CrossRef]

203. Ziegler, E.E.; Jeter, J.M.; Drulis, J.M.; Nelson, S.E.; Haschke, F.; Steenhout, P.; Brown, C.; Maire, J.-C.; Hager, C. Formula with reduced content of improved, partially hydrolyzed protein and probiotics: Infant growth and health. Monatsschrift Kinderheilkd. 2003, 151, S65-S71. [CrossRef]

204. Urban, M.; Bolton, K.; Mokhachane, M.; Mphahlele, R.; Bomela, H.; Monaheng, L.; Beckh-Arnold, E.; Cooper, P. Growth of infants born to HIV-infected women when fed a biologically acidified starter formula with and without probiotics. S. Afr. J. Clin. Nutr. 2008, 21, 28-32. [CrossRef]

205. Velaphi, S.C.; Cooper, P.A.; Bolton, K.D.; Mokhachane, M.; Mphahlele, R.M.; Beckh-Arnold, E.; Monaheng, L.; Haschke-Becher, E. Growth and metabolism of infants born to women infected with human immunodeficiency virus and fed acidified whey-adapted starter formulas. Nutrition 2008, 24, 203-211. [CrossRef]

206. Corthésy, B. Role of secretory IgA in infection and maintenance of homeostasis. Autoimmun. Rev. 2013, 12, 661-665. [CrossRef]

207. Bakker-Zierikzee, A.M.; Tol, E.A.F.; Kroes, H.; Alles, M.S.; Kok, F.J.; Bindels, J.G. Faecal SIgA secretion in infants fed on pre- or probiotic infant formula. Pediatr. Allergy Immunol. 2006, 17, 134-140. [CrossRef]

208. Holscher, H.; Czerkies, L.A.; Cekola, P.; Litov, R.; Benbow, M.; Santema, S.; Alexander, D.D.; Perez, V.; Sun, S.; Saavedra, J.M.; et al. Bifidobacterium lactisBb12 Enhances Intestinal Antibody Response in Formula-Fed Infants. J. Parenter. Enter. Nutr. 2012, 36, 106S-117S. [CrossRef]

209. Taniuchi, S.; Hattori, K.; Yamamoto, A.; Sasai, M.; Hatano, Y.; Kojima, T.; Kobayashi, Y.; Iwamoto, H.; Yaeshima, T. Administration of bifidobacterium to infants with atopic dermatitis: Changes in fecal microflora and clinical symptoms. J. Appl. Res. 2005, 5, 387-396. Available online: https:/ /www.cochranelibrary.com/central/doi/10.1002/central/CN-00569597/full (accessed on 22 November 2021).

210. Matsuda, F.; Chowdhury, M.; Saha, A.; Asahara, T.; Nomoto, K.; Tarique, A.; Ahmed, T.; Nishibuchi, M.; Cravioto, A.; Qadri, F. Evaluation of a probiotics, Bifidobacterium breve BBG-01, for enhancement of immunogenicity of an oral inactivated cholera vaccine and safety: A randomized, double-blind, placebo-controlled trial in Bangladeshi children under 5 years of age. Vaccine 2011, 29, 1855-1858. [CrossRef] [PubMed]

211. Mohan, R.; Koebnick, C.; Schildt, J.; Schmidt, S.; Mueller, M.; Possner, M.; Radke, M.; Blaut, M. Effects of Bifidobacterium lactis Bb12 Supplementation on Intestinal Microbiota of Preterm Infants: A Double-Blind, Placebo-Controlled, Randomized Study. J. Clin. Microbiol. 2006, 44, 4025-4031. [CrossRef] [PubMed]

212. Alcon-Giner, C.; Dalby, M.J.; Caim, S.; Ketskemety, J.; Shaw, A.; Sim, K.; Lawson, M.A.; Kiu, R.; LeClaire, C.; Chalklen, L.; et al. Microbiota Supplementation with Bifidobacterium and Lactobacillus Modifies the Preterm Infant Gut Microbiota and Metabolome: An Observational Study. Cell Rep. Med. 2020, 1, 100077. [CrossRef]

213. Kitajima, H.; Sumida, Y.; Tanaka, R.; Yuki, N.; Takayama, H.; Fujimura, M. Early administration of Bifidobacterium breve to preterm infants: Randomised controlled trial. Arch. Dis. Child.-Fetal Neonatal Ed. 1997, 76, F101-F107. [CrossRef]

214. Stratiki, Z.; Costalos, C.; Sevastiadou, S.; Kastanidou, O.; Skouroliakou, M.; Giakoumatou, A.; Petrohilou, V. The effect of a bifidobacter supplemented bovine milk on intestinal permeability of preterm infants. Early Hum. Dev. 2007, 83, 575-579. [CrossRef] [PubMed]

215. Mihatsch, W.; Vossbeck, S.; Eikmanns, B.; Hoegel, J.; Pohlandt, F. Effect of Bifidobacterium lactis on the Incidence of Nosocomial Infections in Very-Low-Birth-Weight Infants: A Randomized Controlled Trial. Neonatology 2010, 98, 156-163. [CrossRef]

216. Dilli, D.; Aydin, B.; Fettah, N.D.; Özyazıcı, E.; Beken, S.; Zenciroğlu, A.; Okumuş, N.; Özyurt, B.M.; Ipek, M.; Akdağ, A.; et al. The ProPre-Save Study: Effects of Probiotics and Prebiotics Alone or Combined on Necrotizing Enterocolitis in Very Low Birth Weight Infants. J. Pediatr. 2015, 166, 545-551.e1. [CrossRef]

217. Patole, S.K.; Rao, S.C.; Keil, A.D.; Nathan, E.A.; Doherty, D.A.; Simmer, K. Benefits of Bifidobacterium breve M-16V Supplementation in Preterm Neonates-A Retrospective Cohort Study. PLoS ONE 2016, 11, e0150775. [CrossRef]

218. Fujii, T.; Ohtsuka, Y.; Lee, T.; Kudo, T.; Shoji, H.; Sato, H.; Nagata, S.; Shimizu, T.; Yamashiro, Y. Bifidobacterium breve en-hances transforming growth factor $\beta 1$ signaling by regulating smad7 expression in preterm infants. J. Pediatric Gas-Troenterol. Nutr. 2006, 43, 83-88. [CrossRef] [PubMed] 
219. Costeloe, K.; Hardy, P.; Juszczak, E.; Wilks, M.; Millar, M.R. Bifidobacterium breve BBG-001 in very preterm infants: A randomised controlled phase 3 trial. Lancet 2015, 387, 649-660. [CrossRef]

220. Li, Y.; Shimizu, T.; Hosaka, A.; Kaneko, N.; Ohtsuka, Y.; Yamashiro, Y. Effects of bifidobacterium breve supplementation on intestinal flora of low birth weight infants. Pediatr. Int. 2004, 46, 509-515. [CrossRef] [PubMed]

221. Satoh, Y.; Shinohara, K.; Umezaki, H.; Shoji, H.; Satoh, H.; Ohtsuka, Y.; Shiga, S.; Nagata, S.; Shimizu, T.; Yamashiro, Y. Bifidobacteria pre-vents nec and infection in preterm infants. Int. J. Probiotics Prebiotics 2007, 2, 149-154.

222. Hikaru, U.; Koichi, S.; Yayoi, S.; Hiromichi, S.; Hiroaki, S.; Yoshikazu, O.; Seigo, S.; Satoru, N.; Toshiaki, S.; Yuichiro, Y. Bifidobacteria prevents preterm infants from developing infection and sepsis. Int. J. Probiotics Prebiot-Ics 2010, 5, 33-36.

223. Wang, C.; Shoji, H.; Sato, H.; Nagata, S.; Ohtsuka, Y.; Shimizu, T.; Yamashiro, Y. Effects of Oral Administration of Bifidobacterium breve on Fecal Lactic Acid and Short-chain Fatty Acids in Low Birth Weight Infants. J. Pediatr. Gastroenterol. Nutr. 2007, 44, 252-257. [CrossRef]

224. Athalye-Jape, G.; Minaee, N.; Nathan, E.; Simmer, K.; Patole, S. Outcomes in preterm small versus appropriate for gestation infants after Bifidobacterium breve M-16 V supplementation. J. Matern. Neonatal Med. 2018, 33, 2209-2215. [CrossRef]

225. Lin, H.-C.; Hsu, C.-H.; Chen, H.-L.; Chung, M.-Y.; Hsu, J.-F.; Lien, R.-I.; Tsao, L.-Y.; Chen, C.-H.; Su, B.-H. Oral Probiotics Prevent Necrotizing Enterocolitis in Very Low Birth Weight Preterm Infants: A Multicenter, Randomized, Controlled Trial. Pediatrics 2008, 122, 693-700. [CrossRef]

226. Braga, T.D.; Da Silva, G.A.P.; De Lira, P.I.C.; Lima, M.D.C. Efficacy of Bifidobacterium breve and Lactobacillus casei oral supplementation on necrotizing enterocolitis in very-low-birth-weight preterm infants: A double-blind, randomized, controlled trial. Am. J. Clin. Nutr. 2010, 93, 81-86. [CrossRef]

227. Ishizeki, S.; Sugita, M.; Takata, M.; Yaeshima, T. Effect of administration of bifidobacteria on intestinal microbiota in low-birthweight infants and transition of administered bifidobacteria: A comparison between one-species and three-species administration. Anaerobe 2013, 23, 38-44. [CrossRef] [PubMed]

228. Patole, S.; Keil, A.D.; Chang, A.; Nathan, E.; Doherty, D.; Simmer, K.; Esvaran, M.; Conway, P. Effect of Bifidobacterium breve M-16V Supplementation on Fecal Bifidobacteria in Preterm Neonates-A Randomised Double Blind Placebo Controlled Trial. PLoS ONE 2014, 9, e89511. [CrossRef] [PubMed]

229. Totsu, S.; Yamasaki, C.; Terahara, M.; Uchiyama, A.; Kusuda, S. Probiotics Study Group in Japan Bifidobacterium and enteral feeding in preterm infants: Cluster-randomized trial. Pediatr. Int. 2014, 56, 714-719. [CrossRef] [PubMed]

230. Ellis, C.L.; Bokulich, N.A.; Kalanetra, K.M.; Mirmiran, M.; Elumalai, J.; Haapanen, L.; Schegg, T.; Rutledge, J.C.; Raff, G.; Mills, D.A.; et al. Probiotic administration in congenital heart disease: A pilot study. J. Perinatol. 2013, 33, 691-697. [CrossRef] [PubMed] 